\title{
Mizancı Murad'ın Unutulmuş Bir Eseri ve Edebiyat-ı Ahlâkiye Anlayışı Üzerine
}

\section{A Forgotten Work of Mehmed Murad and on The Morality of Literature Approach}

\author{
Esra KÜRÜM ${ }^{1}$
}

'Sorumlu yazar/Corresponding author: Esra Kürüm (Dr. Öğr. Üyesi),

Bitlis Eren Üniversitesi, Fen Edebiyat Fakültesi, Türk Dili ve Edebiyatı Bölümü, Bitlis, Türkiye

E-posta: esra-kurum@hotmail.com

ORCID: 0000-0002-8420-7505

Başvuru/Submitted: 10.08 .2019 Revizyon Talebi/Revision Requested: 25.09.2019

Son Revizyon/Last Revision Received: 24.10.2019

Kabul/Accepted: 06.11.2019

Online Yayın/Published Online: 26.11.2019

Atıf/Citation: Kurum, Esra. "Mizancı Murad'ın Unutulmuş Bir Eseri ve Edebiyat-ı Ahlâkiye Anlayışı Üzerine." Türkiyat Mecmuası-Journal of Turkology 29, 2 (2019): 455-484.

https://doi.org/10.26650/iuturkiyat.651063 öz

Mîzancı Murad, Tanzimat Dönemi'nin en önemli fikir, devlet adamlarından biridir. Ülkenin içinde bulunduğu durum devrin bütün aydınları gibi onu da çareler düşünmeye ve önermeye toplum için çabalamaya itmiştir. Bunun için iktidarın engellemelerine rağmen uzun bir süre Mîzan gazetesini çıkarmış, burada yazılarını neşretmiştir. Bu yazılarda özellikle siyasi görüşlerini dile getirmiştir. Edebi görüşlerini dile getirdiği seri makalelerinde ise eser tenkidi yapmıştır. Edebiyatımızın dünü ve bugünü hakkındaki görüşlerini sıralamıştır. Bununla birlikte edebiyatın nasıl olması gerektiğini de Batı'dan örnekler vererek açıklamıştır. Ona göre edebiyat millî bir karakter taşımalıdır. Edebiyat-ı ahlâkiye adını verdiği bu anlayışa göre yazarlar toplumu iyiye yöneltecek ideal rol modeller yaratmalıdır.

Mîzancı Murad'ın edebiyat anlayışının uygulaması olmak üzere kaleme aldığı tek telif tiyatro eseri bugüne kadar günümüz alfabesine uyarlanmamış ve üzerine neredeyse hiç çalışılmamış bir eser olan Tencere Yuvarlandı Kapağını Buldu adlı eseridir. Dört perdelik bir komedi olan bu eser, toplumsal bir konu olan evlilik konusunu ele almaktadır. Murad Bey, eserde kurguladığı ideal ve karşıt karakterler vasıtasıyla doğru ve yanlış denklemi üzerinden mesajını topluma ulaştırmaya çalışır.

Anahtar kelimeler: Mîzancı Murad, Mîzan, Tencere Yuvarlandı Kapağını Buldu, Edebiyat-ı Ahlâkiye, Edebiyat ve Toplum

\section{ABSTRACT}

Mehmet Murad is one of the most important intellectual and statesman of Tanzimat Reform Era. The condition of the country pushed him to find and suggest solutions for the society, as it pushed the intellectuals of the area. For this, he published Mîzan newspaper for a long period of time, despite the preventions of the government and issued his writings. He mainly voiced his political opinions in these writings. In his serial articles in which he uttered his literary opinions, he made criticisms. He stated his opinions on the previous and current situation of Turkish literature. In addition to this, he explained how the literature should be by giving examples from Western literature. According to him, literature should carry a national identity. According to this approach which he named as morality of literature, writers should create ideal role models that would lead the society to decency. 
The name of the single-written drama which was written by Mehmed Murad for the application of literature approach was "Tencere Yuvarlandı Kapağını Buldu" was not adapted into our current alphabet and it was hardly ever examined. This work which is a four-act comedy discusses the subject of marriage which is a social subject. Mehmet Murad tries to convert his message to the society on the equation of right and wrong through ideal and protagonist characters that he fictionalized in the work.

Keywords: Mehmet Murad, Mîzan, Tencere Yuvarlandı Kapağını Buldu, Morality of Literature, Literature and Society

\section{EXTENDED ABSTRACT}

Mehmet Murad was born in 1854 in Dagestan. He completed his primary education in Dagestan and his high-school education in Russia. Due to the oppression of Russians that he was exposed to since his childhood, he went to Istanbul in 1873 in order to serve the Khalifa and Islam. When he first came to Istanbul, he introduced himself in French since he did not know Turkish and presented his condition by meeting with Mithat Pasha. With the sponsorship of Mithat Pasha, he was assigned to report the news which is summarized in French by following the Russian media to the Ministry of Foreign Affairs. He also served as a teacher of Law and in Teachers' Training School for Boys and performed various tasks of the state. He started to publish Mîzan newspaper in 1886. Mîzan newspaper which was published at intervals and in abroad for a while was an important platform in which Mehmet Murad voiced his opinions and suggestions on political, economic, literary, etc. Mehmet Murad is mostly known with his political identity in his time but he mainly uttered the problems that he observed in political and social life as an intellectual of the time in newspaper columns with his literary identity and wording. In addition to this, he also benefited from literature which was regarded as enlightening at that time. Furthermore, he wrote articles on literary criticism, stated his opinions on some of the works with criticism and even created literary works in which he reflected his poetic manner. Mehmet Murad mentioned his opinions on literary criticism with 18-series of article titled as "Üdebamızın Numune-i İmtisalleri” which were published in Mîzan newspaper and also in some of the literary writings and in the "İfade-i Mahsusa" part of his novel. According to him, literature is a reflection of society. This situation gives an important mission to the littérateurs. The most important aspect of literature which can be exploited by the public is the moral of literature. That is, the aspect of literature which supervises the moral and social rules and serves to improve these. However, according to Mehmet Murad, the least developed aspect of literature for us is this aspect, moral of literature. Mehmet Murad explains the general characteristics of novels and dramas that reflect the moral of literature by stating that the examples of the literary approach which he named as the moral of literature were given as novels and dramas in Western literature. The litterateurs of the area created social characters that are outstanding, epitomic and has talents in heroism and patriotism in their novels and dramas. According to Mehmet Murad, the plot of work should be realistic and natural. In addition to this, it should be appropriate to social moral rules, national culture and the nature of the sense. The work should comply with the real, but it is not enough. In order for the work 
to be regarded as a literary work, it should completely comply with the rules and methods of rhetoric. In addition to this, subjects that would revive national feelings, evoke real life, motivate good behaviors and remove bad behaviors should be chosen.

Positive characters in his novel and drama are ideal characters which have a stance against life with honesty and social ethics. He provides the opportunity for literature to serve to social moral either by including these characters in his works and make the reader envy or include negative characters and make the reader disgust. Mehmet Murad examined the effect of literature on society with Western examples. For this reason, the talent of the writer should be directly proportionate to the correction effect that the writer can carry out in social moral. Talent is attracting attention to the malignancies which escape from the attention of everyone by revealing them effectively, to give up to the correction of connoisseur's benevolence by compiling the problems that were secretly rooted in the moral and customary rules of society to evoke the "noble opinion" by leading everyone to the desired by making them envy and implementing hate to the malignancies and undesired.

"Tencere Yuvarlandı Kapağını Buldu" is the first drama of Mehmet Murad. The work which was published in 1326/1908 in Istanbul is a 4-act comedy. The most conspicuous characteristic of the work is the statement that was expressed after the writer introduces the names, "Although the names are foreign, the main issue is local." This situation is to prevent the criticisms that might be made on the most sensitive subject of the writer. Because the author did not give any information on this subject on his subsequent writings. The point which is touched upon the most in the criticisms of the writer is the disorderly conduct against national morality, customs and Islamic rules. In a Western-style work in which the subject is marriage, it is necessary for women and men to come together or to mention situations that can be considered as illegitimate for the writer to reach his purpose. Whereas, it would be unreal for characters who live by the Islamic rules to experience situations that would arise conflict. It would make Mehmet Murat the target on the subject that he criticizes. This approach in his drama is quite appropriate with the poetic approach of Mehmet Murad.

The subject of the work is prearranged marriages which is the subject of several dramas of the era. However, he brings a different perspective from the work of Şinasi which is Şair Evlenmesi. Although Mehmet Murad chose marriage as a subject, the message he wants to give is different. While Şinasi draws attention to the problems that may arise from prearranged marriages, Mehmet Murad wants to draw attention to the error of marriages that would be made without taking into consideration the social moral, national and moral values or marriages that would be made for interest. However, the common points of these works are that they draw attention to social corruptions and the subject is smoothed over at the end of the incident. Şair Evlenmesi tries to give its message on the element of humor. However, the element of humor is scarce in Tencere Yuvarlandı Kapağını Buldu. The writer attempts to force literature to serve for moral in each opportunity through monologues and dialogs. 
The plot summary of the play is as follows. Monsieur and Madam Loan are the parents of Mademoiselle Mari. There is a candidate for Mademoiselle by the name of Ernest Lömon. This young man who is a prodigal wants to marry because he knows the disposition of his chief in his workplace to the young women, that is, the wives of his employees and wants to be promoted. Nobody finds it appropriate for Mari and Ernest to marry, except for her mother and her cousin Sofi. Her prudent father approves an architect by the name of Vayan for his daughter. However, they have a dispute between them that arises from their occupation. This dispute is resolved at the end of the play as well. In the end, everyone decides to marry the person they desire to.

Mehmet Murad, who stated his theoretical opinions on literature with series of articles titled as "Üdebamızın Numune-i İmtisalleri” in Mîzan newspaper, tried to put this into practice through two of his works. In both of his works, he is moved by the idea that the literature should serve to reform and improve the social moral. This situation required to fictionalize ideal characters in both of his works. Mehmet Murad desires the society and the country to be composed of the prototypes he created in his work in the future. Thus he would serve to his country, Islam and his people with his pen as an intellectual. 


\section{Mîzancı Murad Bey Kimdir?}

Mehmet Murad Bey, 1854 yılında Dağıstan'ın Dargu Cumhuriyeti kısmında dünyaya gelmiştir. Mehmed Murad yedi yaşında halasının kocasından Arapça dersi almıştır. Gösterdiği başarı hocasının dikkatini çekmiş ve onun eğitimine İstanbul'da devam etmesi tavsiyesinde bulunmuştur. ${ }^{1}$ Daha sonra kendi isteği ile Timurhan Şûra Rüştiyesine başlamıştır. Eğitim süresi altı yıl olan bu okulun, üç yıl sürecek birinci sınıfında Rusça okuma ve yazma öğretilmektedir. Murad Bey, bu okulu mizacındaki daima en iyi olma arzusu ile çalışarak bir buçuk yılda bitirip İstavropol İdadisi'ne kaydolmuştur. ${ }^{2}$

Lise yılları boyunca da geleceğini idealine hizmet etmek dairesinde şekillendirme planları yapmaktadır. Rusların baskıları karşısında küçük yaştan beri var olan İstanbul'a gidip halifeye ve İslam dinine hizmet etme arzusunu daha fazla erteleyemeyerek 1873 y1lında İstanbul'a gelmiştir. ${ }^{3}$ İstanbul'a gelmek için gerekli yol parasını bile yazdığg birkaç makale vasıtası ile kazanmış olan Mehmed Bey'in İstanbul'u ilk gördüğündeki izlenimlerini Turfanda mı Yoksa Turfa $m \imath ?^{4}$ adlı eserinde Mansur adlı karakterinin dilinden müşahede ederiz. Batum yolu ile 2 Şubat 1873 'te İstanbul'a geldiğinde 20 yaşındadır. İstanbul'a gelince ilk olarak Mithat Paşa ile görüşerek Türkçe bilmediği için Fransızca kendini tanıtmış durumunu arz etmiştir. Mithat Paşa'nın da himayesi ile Hariciye Kalemi'nde Rus basınını takip ederek haberlerin Fransızca özetlerini Nezarete vermekle görevlendirilir. Matbuat-1 Dâhiliye Kalemi’nde çalışırken aslen Kafkasyalı olan Maliye Nazırı Şirvanizade Mehmed Rüşdü Paşa'nın himayesini görür. Konağına yerleşmiş, bir süre sonra da mühürdarı olmuştur. ${ }^{6}$ Bu vesileyle de diğer devlet adamlarının da muhabbet ve teveccühlerini kazanmıştır. Murad Bey'in İstanbul'da edindiği bu yüksek çevre aslında onun için önemli bir talihtir. Buna karşılık, daha ilk anlarında kendisine gülen bu talihin öbür yüzünde, memur olarak girip çıktığı dairelerde gördüğü, rüşvet, kayırma, cehalet ve idaresizliklere dair müşahedeleri vardır. Genç Murad'ın yıllar sonra, romanının dördüncü bölümünde "Mübaşeret ve İlk Meyusiyet" başlığı altında hikâye edeceği bu haller, kendisini şiddetle 1slaha muhtaç Osmanlı bürokrasisi ile karşı karşıya getirir." ’7 Murad Bey’in İstanbul'a geldiği yıllar Osmanlı Devleti'nin içerde ve dışarda bunalımlı yıllarıdır. Bu yüzden Avrupa'ya gitmek lisan ve bilgi açısından eksiklerini tamamlamayı düşünür ancak Şirvanizade Rüşdi Paşa mâni olmuştur. Murad Bey, İstanbul'a geldikten kısa bir süre sonra Hilmi Molla'nın kızı Hasibe Hanımla evlenmiştir (1877). Evlenince Şirvanizade konağından ayrılarak hayatının geri kalanını geçireceği Anadolu Hisarındaki yalısına yerleşmiştir. ${ }^{8}$ Bu sırada yeni açılan Mekteb-i

1 Fevziye Abdullah Tansel, "Mîzancı Mehmed Murad Bey”, İstanbul Üniversitesi Edebiyat Fakültesi Dergisi, 2/3-4 (1952): 71.

2 Birol Emil, Mîzancı Murad Bey Hayatı ve Eserleri (İstanbul: Kitabevi, 2009), 18.

3 Abdullah Uçman, "Mîzancı Murad” İslam Ansiklopedisi, c.30, (İstanbul: Diyanet Vakfı Yayınevi, 2009a), 214216.

4 Mehmed Murad Mîzanc1, Turfanda mı Yoksa Turfa mı? (İstanbul: Sis Yayıncılık, 2013).

5 Tansel, "Mîzancı Mehmed Murad Bey", 71.

6 Uçman, "Mîzancı Murad”, 214.

7 Emil, Mizancı Murad Bey Hayatı ve Eserleri, 39.

8 Emil, Mizancı Murad Bey Hayatı ve Eserleri, 41. 
Mülkiye-yi Şahane'nin tarih hocalığı için açılan müsabakayı kazanarak on yedi yıl boyunca bu görevi yerine getirmiştir. Ayrıca Hukuk ve Dârülmuallimîn'de de hocalık yapmıştır.9 Murad Bey, hocalık vazifelerinin yanı sıra, Muhtelit Muhacirin Komisyonu üyeliği ${ }^{10}{ }^{10}$ Maarif Nezareti Teftiş, Muayene Heyeti Üyeliği ve Dârülmuallimîn müdürlükleri görevlerini (1879-1882) de ifa etmiştir. ${ }^{11}$ Mülkiye hocalığı, devlet memuriyeti yapmaktan memnun olmayan Murad Bey için bir kurtuluş kapısı olmuştur. Çünkü 'Bâbıali' de memurların sorumsuz ve liyakatsiz halleri, terfilerdeki keyfilik, kayırma ve rüşvetin usulden sayılması henüz yolun başındaki genç idealisti rahatsız eder. Amirleriyle sık sık çekişir." ${ }^{12}$ Bu arada bir aralık memleketi Dağıstan'1 ziyaret edip döndükten sonra Mîzan gazetesini çıkarmaya başlar. ${ }^{13}$

Murad Bey’in ilk makalesi "Hal-i Hazır ve Ecnebi Müdahalesi” adıyla Vakit gazetesinde yayımlanır. İkinci makalesi ise "Ahval-i Hazıra Münasebetiyle İttihaz Olunacak Tedâbir-i Lâzıme" başlı̆̆ı ile İttihad gazetesinde çıkmıştır. ${ }^{14}$ İlk yazılarını Mehmed M. D. İmzasıyla ve yabancı gazetelerin saldırılarına müdafaa mahiyetinde kaleme almış ve neşretmiştir. Hatta yazılarında Rusya'nın gücünden bahsetmesini yaşadığı hayatın sakinliği ve münzeviyânesini de dikkate alarak, kötü niyetli bazı kişiler Rus casusu olduğunu ileri sürmüşlerdir. Bir süre sonra haftada beş mecidiye karşılığında Vakit gazetesi yazı heyetine dâhil olmuş ancak ücreti az bulduğundan ayrılmıştır. ${ }^{15}$ Murad Bey daha sonra adının da birlikte anılacağı Mîzan gazetesini açmak için teşebbüslerde bulunur. Said Paşa'nın sadareti sırasında memurluktan istifa etmeyi ve Mîzan gazetesini neşretmeyi tasarlayan Murad Bey’in bu isteği ancak Kamil Paşa sadarete geçince yerine getirilmiş, gazeteyi neşretme müsaadesi almıştır. ${ }^{16}$ Kapı memuriyeti ve Dârülmuallimîn' deki çekişmelerden hayli sıkıılmış olan Murad Bey, gördüğü kötü gidişatı önleyebilmek için kamuoyunu uyarıp aydınlatacak bir vasıta arayışı içindedir. Bu bakımdan Mîzan, yalnız halkı değil, sorumsuz rezil çevresine kurban olmuş padişahı da haberdar edecek 1şık saçan bir fanus olarak bu görevi yerine getirmiş olacaktı. ${ }^{17}$ İdealini gerçekleştirebileceği bir faaliyet sahası olmak üzere neşrine hazırlandığı Mîzan gazetesi, "Murad Bey’in hem şöhreti, hem felaketi olmuştur. Bu gazete, adını İstanbul sınırları dışına çıkararak imparatorluk coğrafyasına yaymış, kendisini Osmanlı basınının birinci sınıf münekkid ve mütefekkir muharriri yapmıştı. Fakat yine bu gazete, sonunda darağacından geçerek Rodos menfâsında nihayet bulacak olan bir maceraya sebep olmuştu." ${ }^{18}$ Önceleri II. Abdülhamid'in teveccühünü de kazanan Mîzan,

9 Tansel, "Mizancı Mehmed Murad Bey", 75.

10 Uçman, "Mizancı Murad", 214.

11 Emil, Mizancı Murad Bey Hayatı ve Eserleri, 57.

12 Emil, Mizancı Murad Bey Hayatı ve Eserleri, 49.

13 Uçman, "Mizancı Murad", 214.

14 Emil, Mizancı Murad Bey Hayatı ve Eserleri, 45.

15 Tansel, "Mizanc1 Mehmed Murad Bey", 76.

16 Tansel, "Mizanc1 Mehmed Murad Bey", 76.

17 Mehmed Murad Mizanc1, Meskenet Mazeret Teşkil Eder mi? haz. Aladdin Fidancı, (İstanbul: Şehir Yayınları, 2005), 78.

18 Emil, Mizancı Murad Bey Hayatı ve Eserleri, 59. 
eleştirinin dozunu giderek arttırınca sansür tarafından zaman zaman kapatıldı. ${ }^{19}$ Mîzan 'ın ilk sayısı 21 Ağustos 1886 tarihinde çıkmıştır. Bu sayıda gazete ve gazetecilik hakkında bilgi verilmiş ve Mîzan ’n içeriği ve prensipleri hakkında yazılar yer almıştır. Mîzan yayın hayatı boyunca, bir haber gazetesi olmaktan ziyade fikir politikacılığı organı niteliğindedir. Gazete hem iç hem dış politika hakkında hem haber hem fikir beyanını misyon edinmiştir. "İç Siyaset" başlığı altında devlet, rejim meselesi, yöneticiler, iktisat, maliye, eğitim öğretim ve sanayi konuları ile fakirlere yardımdan fuhuşun yasaklanmasına kadar dönemin hemen bütün sosyal meselelerini ele almıştır. ${ }^{20}$ Murad Bey, başyazısında gazeteyi taşradaki ahalinin haftalık gelen gazetelerde aynı haberleri mükerrer kereler görmek zorunda kalmasından dolayı çıkardıklarını ifade etmektedir: ${ }^{21}$ Murad Bey'in bu düşünce ile gazete neşretmesi İstanbul'a gelmeden önceki dönemde İstanbul'dan gelen gazetelere ulaşma konusunda yaşadığı sıkıntılardan kaynaklanıyor olmalıdır. Murad Bey, Abdülhamid ile birkaç görüşmesinin sonucu aslında kötü biri olmadığ 1 kanaatine varmıştır. Ona göre idari aksaklıkların müsebbibi Babıali'dir. ${ }^{22}$ Mîzan gazetesinin ilk devresi ile diğer devreleri arasında yönetime yakınlık açısından büyük bir tezat vardır. $\mathrm{Bu}$ devrenin bütün sayılarında her konuda Abdülhamid zikredilerek her defasında övülmüştür. Her gelişme ve her hamle onun iktidar ve iradesi eseri olarak alkışlanmıştır. Ancak bu tavır çaresizlik veya mecburiyet eseri değil, Murad Bey'in samimi tavrıdır. Mîzan gazetesinin 43 . sayısına kadar saray ile kurulan iyi ilişkiler devam eder. İlk defa bu sayıda gazete sansüre uğrar. Ardından 94. sayısında yayımlanan bir bent, Kamil Paşa aleyhinde algılanarak altı aylık kapatma cezası verilir. Ardından beş sayı yayımlandıktan sonra tekrar kapatılır. Bundan sonra Mîzan artık sık sık sansüre uğrar ve aralıklarla kapatma cezası alır. Bütün bu durumlar uzunca bir süre Murad Bey’de Saray aleyhinde bir düşünce oluşturmamıştır. ${ }^{23}$

Gazetenin birinci devresinde konular ağırlıklı olarak iç ve dış siyasete ilişkindir. Mısır ve Girit meseleleri, Şarki Rumeli, Osmanlı Avrupa ilişkileri dış politikanın ana gündem maddeleridir. Murad Bey, yazılarında rejim meselesinde Saray yanlısı bir tutumla parlamenter sistem aleyhine bir duruş sergilemektedir. Gazetenin iç politika gündemini ise kapitülasyonlar, yabancı sigorta ve piyango şirketleri konusu, Reji İdaresi ve Düyûn-1 Umûmiyye, demiryolları meselesi, iktisat, maliye, maarif, basın, Bâbıâli ve memur maaşları konuları yanında posta idaresindeki aksamalar, bankalar, şehirdeki yangınlar, dinî günler gibi çok çeşitli hususlar oluşturmaktaydı. Murad Bey, hemen her sayıda neşrettiği "Vazife ve Mesuliyet” başlıklı yazılarıyla siyasi görüşlerini dile getirmiştir. 1888-1889 yıllarında "Üdebâmızın Numûne-i İmtisalleri” başlığ 1 ile neşrettiği seri makaleleri ile de edebiyat ve tenkitle ilgili görüşlerini dile getirmiştir. Genel olarak, "Edebiyyat-ı ahlâkiye” adını verdiği bir anlayışla kaleme aldığı

19 Uçman, "Mizancı Murad", 215.

20 Uçman, "Mizancı Murad", 215.

21 Hilmi Ziya Ülken, Türkiye 'de Çağdaş Düşünce Tarihi (İstanbul: Ülken Yayınları, 2005), 126.

22 Tansel, "Mizanc1 Mehmed Murad Bey", 76.

23 Gülbeyaz Karakuş, Osmanlı Siyasi Düşüncesinde Yeni Üslup Arayışları Mizan Gazetesi Örneği (Yüksek Lisans Tezi, Marmara Üniversitesi, 2007), 24. 
bu makalelerde, edebiyatın millî karakter taşıması gerektiğini savunur. Ona göre, edebi eser, toplumun örf, anane ve dini kurallara bağlı kalınarak kurgulanan örnek tipler sunmalıdır. ${ }^{24}$

Sadrazam Kamil Paşa'nın muhalefetine rağmen Padişah, Murad Bey’i Düyun-1 Umumiye komiserliğine tayin ettirir. Mîzancı Murad'ın Düyun-1 Umumiye macerası ona ülkede bürokrasinin işleyişini yakından müşahede fırsatı vermiştir. Bu vazife esnasında yaptıklarını kesinlikle ülkenin menfaatlerini düşünerek yaptığından tam emniyette olmakla beraber aslında bütün devlet ricalinin böyle davranmasının ülkeyi o günkü durumundan başka bir yere götüreceğinden emindir. Murad Bey’e göre en büyük problem, miskinliğimizdir. Ama bu mazeret olmamalı herkes üzerine düşeni fedakârlıkla, millete muhabbet ve bağlılıkla yapmalıdır:

\begin{abstract}
"Vekillere nisbetle ben, pek küçük bir memur idim. Bununla beraber emanet edilen vazifem dairesinde, ne Yıldız'a, ne Bab-1 Ali ile Hazineye, ne de ecnebilere tecavüz ettirmedim. Verdikleri mühim kararlarını, hatta kesin iradelerini geri aldırır idim. Demekdir ki, o asrın vekilleri ve yüksek ricalinde, az çok, vazife ve mesuliyet dairelerine vukuf, fedakârlığa kendilerinin sevk edecek kadar millete muhabbet ve bağl11ıkları olsa idi, İkinci Abdülhamid devri, o kadar tiksindirici, bir istibdat şeklini almazdı. Yani tarih nazarında Sultan Hamid ağır surette mesul olmaktan kurtulmaz. Lakin başta Said ve Kamil Paşalar olmak şartıyla, vekillerin mesuliyetleri daha fazla olsa gerekir. Çünkü meskenet ve mahviyet mazeret teşkil edemez." ${ }^{25}$
\end{abstract}

Düyun-1 Umumiye müfettişliği esnasında Padişah II. Abdülhamid, Murad Bey’den memleketin hayrı adına idarenin düzeltilmesi hakkında bir rapor istemiştir. Murat Bey’in oldukça uzun ve tafsilatlı hazırladığı raporu okuyan Padişah, Murad Bey'in huzuruna kabulünü istemiş ve bizzat görüşmüştür. Bu görüşmeden oldukça iyi intiba ve mutmain bir kalple ayrılan Murad Bey, padişahın tekrar görüşme emrine ve vaadine rağmen kendisini bir daha huzura kabul etmeyişi karşısında tamamen ümitsizliğe kapılmıştır. Son görüşme talebinin de Padişah tarafından cevapsız bırakılması neticesinde memleketi terk etme kararı almıştır.

Murad Bey, büyük ideallerle, sadakat ve itaatle halifeye hizmet için geldiği İstanbul'dan yirmi iki yıl sonra Halifeye isyanla ve gizlice kaçmıştır. Viyana'da Avrupa diplomasisi ve yüksek siyaset çevreleri ile iletişim kurmuştur. Bunun amacı Avrupa siyasi çevrelerine Şark meselesinin esasını aktarabilmektir. Bu onun Avrupa'ya gelirken gerçekleştirmeyi düşündüğü projelerinden biridir. ${ }^{26}$ Mîzancı, Viyana'da gördüğü atmosfer ve yazılı basının Osmanlı'nın taksimi hakkında yaptıkları yayınlardan eseflenerek İkinci Abdülhamid Han'a sunulmak üzere çok sert dille bir mektup yazar. Mektupta kendisini Avrupa'ya gelmek zorunda bırakan sebepleri sıralayarak, hükümetin yanlış politikalarının sebep olduğu kötü durumları ve galeyana gelen gençleri önlemenin bu gidişle mümkün olamayacağını belirterek mektubunun sonunda padişaha iki şart ve on gün mühlet sunarak tabiri yerindeyse ültimatom verir gibidir. Oldukça cüretkâr bir üslubu olan bu mektubun özellikle dikkate değer son bölümü şöyledir:

24 Abdullah Uçman, "Mizan” İslam Ansiklopedisi c.30 (İstanbul: Diyanet Vakfı Yayınevi, 2009b), 213-214.

25 Mizanc1, Meskenet Mazeret Teşkil Eder mi?, 197.

26 Emil, Mizancı Murad Bey Hayatı ve Eserleri, 93. 


\begin{abstract}
"Memleketin bu gün içinde bulunduğu şartlar davanın sulh ve sükûnet içinde tesviye edilmesini emreder. Bunun için de iki çare vardır; bunlardan birinin ihtiyarına himmet buyurulması, damarlarında akan Ertuğrullar, Osmanlar, Orhanlar, Fatihler, Yavuzlar kanından beklenir. Bu iki çare de, hak-i pay-i şahaneye takdim ettiğim kontrol meclisi layihası münderecatında daha geniş olarak meşveret usulünü ihdas ile efkârı teskin etmek yahut hükümeti terk eylemektir. Vaziyete çare olabilecek üçüncü bir tedbir yoktur. Bunun için ikiden birini ihtiyar etmekten nükûl kendi nefsi için memleket ve devletin bekasını feda eylemek manası çıkacaktır. (...) İşbu iki şıktan birinin ihtiyar olunduğu haberine on gün kadar intizar edeceğim. Bu müddet geçince hareket hürriyetimi tamamıyla iktisap eylemiş bulunacağım." ${ }^{27}$
\end{abstract}

Murad Bey 30 Kasım Cumartesi günü geldiği Viyana' dan ayrılarak 5 Aralık 1895 Perşembe günü Paris'e gelir. ${ }^{28}$ Aslında Mîzancı'nın asıl niyeti buradaki Jön Türkleri kendi liderliği ve fikirleri ile idare etmektir. Ancak Jön Türkleri o vakitte idare eden Ahmed Rıza Bey tarafından ilk karşılaşmada beklediği kabulü göremez. Bunun sebebi olarak Ahmed Rıza Bey, Murad Bey hakkında çıkan Yıldız'ın gönderdiği bir casus olduğu dedikodusunu öne sürer. ${ }^{29}$ Mîzancı Murad, Ahmet Rıza'nın çevresinde toplanan, ancak onun aşırı pozitivist, sert görüş ve tutumlarından rahatsız olan Muhafazakâr Jön Türklerin başına geçmiştir. 1897'de Paris'te Ahmed Rıza grubu ile Mîzancı Murad grubu arasında yaşanan anlaşmazlık nedeniyle ${ }^{30}$ Paris'te de kalmak istememiş Mısır'a geçmiştir. Mısır'a geçtikten on beş gün sonra 4 Kanunisani 1311 (1896)'de Mîzan'ın ilk nüshasını çıkarmıştır. Bu nüsha vaktiyle İstanbul'da neşrettiği ve 158. Sayıda bıraktığı Mîzan 'ın devamıdır ve 159. sayıdır. ${ }^{31}$ Mîzan'ın, Abdülhamid'i hedef alan yazılar yayınlaması karşılığında Murad Bey için İstanbul'da gıyabi idam kararı çıkarılır. İstanbul basını da boş durmaz. Murad Bey aleyhinde kampanyalar başlatır, gerek ailesi üzerinden gerek şahsı üzerinden birçok ithamlara maruz kalır. ${ }^{32}$ Hakkında çıkan idam kararının etkisi ve İstanbul'dan gelen baskılara dayanamayan Mısır yönetimi, Mısır'1 terk etmesi yönündeki telkinlere başlar. Bunun üzerine Murad Bey Mısır'dan tekrar Avrupa'ya gidip cemiyete resmen katılarak faaliyetlerine orada devam etme kararı alır. Bu kararını, Mısır Hükümetinin kendisine ilettiği uyarıyı bildiren bir yazı ile okuyucularına Mîzan'da duyurur. ${ }^{33}$

Paris'e giden Mîzancı, 14 Aralık 1896'dan itibaren Mîzan'ın yeni sayılarını burada neşretmeye başlar. Mîzan gazetesinin III. Devresi olan bu dönem 18 sayı sürmüştür. 1924. Sayılar ise Cenevre'de neşredilecektir. ${ }^{34}$ Serhafiye Ahmed Celaleddin Paşa'nın padişah adına birtakım vaatleri ve 1897 Türk Yunan Muharebesi’nin zaferle sonuçlanması üzerine II.

27 Ahmet Cemaleddin Saraçoğlu, Unutulan Meşhurlarımızdan Mizancı Murad (İstanbul: Şema Yayınları, 2005), 93.

28 Emil, Mizanci Murad Bey Hayatı ve Eserleri, 93.

29 Emil, Mizancı Murad Bey Hayatı ve Eserleri, 93.

30 Ferihan Polat ve Gündüz Derer, “Türk Siyasi Tarihinde Muhafazakâr Batılılaşma Yanlısı Bir Jöntürk: Mizancı Murad” Uluslararast Sosyal Araştırmalar Dergisi, 9/43 (2016): 882-890.

31 Tansel, "Mizanc1 Mehmed Murad Bey", 80.

32 Gülbeyaz Karakuş, "Osmanlı Siyasi Düşüncesinde Yeni Üslup Arayışları Mizan Gazetesi Örneği”, 40.

33 Gülbeyaz Karakuş, “Osmanlı Siyasi Düşüncesinde Yeni Üslup Arayışları Mizan Gazetesi Örneği”, 41.

34 Emil, Mizancı Murad Bey Hayatı ve Eserleri, 325. 
Abdülhamid'in ilan ettiği genel af ve biraz da aile hasretiyle cemiyetin reisliğini birakarak İstanbul'a dönmüştür (A ğustos 1897). Fakat verilen sözlerin hiçbiri gerçekleşmediği gibi İstanbul'a döner dönmez göz hapsine alınır. 1899'da Şura-yı Devlet Maliye Dairesi üyeliğine getirilir. 1908'de II. Meşrutiyet'in ilan edilmesiyle istifa ederek 30 Temmuz 1908'de Mîzan'1 tekrar çıkarmaya başlar. ${ }^{35} \mathrm{Bu}$ devre Mîzan gazetesinin İstanbul'da yeniden neşredilmesiyle başlanılan dördüncü devresidir. 24 Nisan 1909 tarihine kadar neşredilen Mîzan, günlük gazete olarak 135 sayı boyunca fikri ve eleştirel özelliğini kaybetmeden okuyucusuna ulaşmaya devam eder. Mîzan gazetesi bir süre sonra İttihat ve Terakki karşısında muhafazakâr cephenin savunucusu ve sözcüsü vazifesini üstlenir. ${ }^{36}$ Gazete, iktidardaki İttihat ve Terakki Fırkası'na şiddetle muhalefet edince kapatılır.

Mîzancı Murad, daha sonra, 31 Mart Vak'ası'nın tahrikçileri arasında bulunduğu ileri sürülerek müebbet kalebentlik cezasına çarptırılır ve Haziran 1909'da Rodos'a sürgüne gönderilir. ${ }^{37}$ Nihayet Hüseyin Hilmi Paşa kabinesinin çıkardığı kısmi af üzerine 1912 Nisanında tekrar İstanbul'a dönmüştür. ${ }^{38}$ İmparatorluğun savaş öncesi ve savaş yılları Murad Bey için de zor yıllar olmuştur. Bu sırada Peyam ve Peyam-1 Edebi sütunlarında son yazılarını neşretmiştir. Nihayet, 15 Nisan 1917 tarihinde Anadoluhisarı'ndaki yalısında vefat etmiş ve Anadoluhisarı mezarlığına defnedilmiştir. ${ }^{39}$

\subsection{Mîzancı Murad'ın Edebi Kimliği ve Edebiyat-ı Ahlâkiye Anlayışı}

Mîzancı Murad yaşadığı dönemde daha çok politik kimliği ile tanınmış bir şahsiyettir ancak o devrinin aydını olarak siyasi ve toplumsal hayatta gördüğü aksaklıkları genellikle gazete sütunlarında edip kimliği ve üslubu ile dile getirmiştir. Bununla birlikte toplum için o dönemde aydınlatıcı olarak görülen edebiyattan da istifadeye çalışmıştır. Edebiyat tenkidi ile ilgili makaleler yazmış, kimi eserleri tenkitle düşüncelerini sıralamış hatta poetik tavrını yansıttı̆̆ 1 edebi eserler meydana getirmiştir.

Mîzancı Murad edebi tenkitle ilgili görüşlerini Mîzan gazetesinde neşrettiği “Üdebamızın Numune-i İmtisalleri” başlıklı 18 seri makaleyle, ayrıca yine Mîzan'da yayımladığı birkaç edebi musahâbede ve romanının "İfade-i Mahsusa" kısmında dile getirmiştir. ${ }^{40}$

Mîzancı Murad'ın edebiyatı değerlendirme şekli daha çok edebiyatın milletin ahlâk ve millî yaşayışına yaklaşımı açısındandır. Ona göre edebiyat, "bir kavmin terceme-i ahvali ve hayat-1 maneviyesidir... Bir heyet-i ictimaiye-i beşeriyenin her hal ve şanı, yani ve etvâr ve ahlâkı, edep ve terbiyesi, emel ve arzusu hep mahsulât-1 efkârı câmi olan âsar-1 edebiyesinden

35 Uçman, "Mizancı Murad", 215.

36 Emil, Mizancı Murad Bey Hayatı ve Eserleri, 336.

37 Uçman, "Mizancı Murad", 215.

38 Emil, Mizancı Murad Bey Hayatı ve Eserleri, 187.

39 Uçman, "Mizancı Murad", 215.

40 Emil, Mizancı Murad Bey Hayatı ve Eserleri, 383. 
müsteban olur." ${ }^{\text {11 }}$ Edebiyat bir toplumun aynasıdır. Bu durum edebiyatçılara önemli bir misyon da yüklemektedir. Bu bakımdan bir millet binlerce yıl önce yeryüzünden silinmiş olsa bile elimizde edebi eseri varsa bu o milleti bugün tavsif için yeterli olacaktır. Murad Bey, medeni milletlerin medeniyet derecesinin bilimsel eserlerinden ziyade edebi eserlerinden anlaşıldığını öne sürmektedir. Zira bilim her memlekette varlığını sürdürebilecekken edebiyat mutlaka bir vatanın mahsulü olmak zorundadır. Ne kadar ustalıkla taklidi yapılırsa yapılsın bir milletin edebi eserleri bir başkasında daima yabancı kalacaktır. Kendi edebi eseri gibi zevk vermeyecektir. "Yani sanat ve azametiyle hayran edebilir, lakin ateşiyle 1sıtamaz." ${ }^{42}$ Edebiyat toplumun aynası olduğu kadar gelişmesine de vasıta aracıdır. Bunun için edebiyat belli ahlâki kuralları haiz olmalıdır. Murad Bey’e göre edebi eser mensubu olduğu milletin ahlâki kurallarını muhafazayla beraber daha iyileşmesine de hizmet etmelidir. "Medeniyet ve cemiyetlerin belli başlı gelişme vasıtası, aynı zamanda da aynası olan edebiyat, ancak muayyen bir ahlâk telakkisine bağlı olduğu takdirde bu rolünü ifa edebilir." ${ }^{\text {"3 }}$

Edebiyatın, halkın faydasına hizmet eden en önemli tarafı edebiyat-1 ahlâkiyedir. Yani edebiyatın ahlâki ve toplumsal kuralları gözeten geliştirmeye hizmet eden tarafidır. Ancak Murad Bey'e göre bizde en az gelişen edebiyat yönü işte bu edebiyat-1 ahlâkiyedir. "Edebiyat-1 ahlâkiye temayülât-ı hayvâniyenin teskini için bir tarik irae etmek yahut cemiyetin ahval-i hâzıra-i maneviyesini tasvir eylemek ile iktifa etmeyip, âmâl-i millîyeye verdiği cazibeli eşkâl ve suver sayesinde ahvâl-i müstakbeleye icra-yı tesir ve gayret-i millîyeyi bir takım makasıd-1 celileye doğru sevk ve tahrik etmekle mükelleftir." ${ }^{44}$

Namık Kemal gibi, Mîzancı Murad da Divan Edebiyatı'nı ahlâk dışı bulur. Oysa edebi eserin her yönüyle topluma örnek olması gerekir. Ona göre, biz İslamiyet'i tercih ettikten sonra örnek olarak gözümüzü Arabistan'dan, İslam ahlâkından uzaklaşmış olan İran'a çevirme gafletinde bulunduk. Bu bakımdan Mîzancı Murad'a göre Klasik Edebiyat, iki üç yüz senelik bir hâb-1 gaflettir. ${ }^{45}$ Edebiyatımız bu gaflet uykusundan yaklaşık on beş yirmi senedir uyanmaya ve ilerlemeye başlamıştır. Mîzancı Murad'a göre birçok telif eser yazılmasına rağmen Batı edebiyatına nispetle bizdeki terakki çok yavaştır. Ayrıca bir diğer sorun da ortak bir yol kabul edilememiş olmasıdır. Bu yüzden dönemin yazarları farklı edebi anlayışlar benimsemişlerdir. Bu anlayışları ise şöyle sıralamaktadır: "Bir grup edebiyatı Arap taklitçiliğinde aramaktadır; bir diğer grup edebiyatımızın ilerlemesinin tek yolu olarak Batı taklitçiliğini görmektedir; "bir grup da var ki sırf taklit ile bir şey elde edemeyeceğimizi söyleyerek edebiyatımız için kendi “istidâd-1 mahsus”una göre bir yol seçip, Doğu ve Batı'da göreceğimiz güzelliklerden

41 Mehmed Murad Mizancı, "Üdebamızın Numune-i İmtisalleri”, Yeni Türk Edebiyatı Antolojisi III içinde, haz. M. Kaplan, İ. Enginün, B. Emil, Z. Kerman (İstanbul: İstanbul Üniversitesi Edebiyat Fakültesi Yayınları, 1979), 379 .

42 Mizanc1, “Üdebamızın Numune-i İmtisalleri”, 380

43 Birol Emil, "Mizancı Murad Bey’in Edebiyat Ve Tenkide Dair Görüşleri” Türk Dili ve Edebiyatı Dergisi 19 (1971):119143. Erişim 10 Mayıs 2019. http://journals.istanbul.edu.tr/iutded/article/viewFile/1023017660/1023016903.

44 Mizanc1, "Üdebamızın Numune-i İmtisalleri”, 380.

45 Uçman, "Mizancı Murad", 215. 
dilimizin ve fikrimizin şivesine uygun olanlarını kabul ederek fikrin ve içtihadın mahsulü denilecek ciddi bir meslek yolunda ilerleme taraftarı oluyor." 46

Mîzancı Murad, edebiyata dair görüşlerini şiire de intibak ederek değerlendirmelerde bulunmuştur. Onun güzel şiir tarifi şöyledir: "Bizce şiirin en güzeli, mütalaasından sonra en ziyade tesir-i lâtif hâsıl ederek kalbi tatlı hissiyata ve nihayetsiz hayallere sevk edenidir. Şiir mevzuunun kanun bendi yahut fen fikrası gibi mutlaka doğru ve muvafik-1 hikmet olması iktiza etmez. Lakin hayali hoş olmayan manzume şiir olamaz. Kıt'a-i manzumenin elfâzındaki letafet, hiçbir vakitle manasındaki letâfât ve 1ttıradın hâsıl edeceği tesir kadar güzel bir tesiri mûcib olmaz." ${ }^{47}$

Murat Bey, şiirimizin kalıplaşmış ve sürekli tekrar edilen ifadelerden ve şekil mükemmeliyetçiliğinden kurtarılması gerektiğine inanır. Şiirde mananın ön planda olması gerektiğini savunur. Bu nedenle Muallim Naci'nin de bu yönde hareket etmesini istemiştir. ${ }^{48}$ Oysa Naci, gençleri eski edebiyatın şekil ve kelimeciliğine yönlendirmiştir ve alıştırmıştır: "Eğer Naci Efendi tenkidâtını mânâya, esasa hasrederek elfâzı ikinci derecede görmüş olsa ve ümem-i âliyenin bedâyi-i edebiyesini lisanımıza nakle hizmet etseydi -ki iktidarı buna müsâit olduğuna bizce şüphe yoktur - edebiyatımızı cidden terakki ettirmiş olurdu. Şu halde ise fikr-i âcizânemizce tedennî ettirdi. Çünkü birçok nevresidegânı yine eski yolda pûyân olmaya ve manâdan ziyade elfâza ehemmiyet vermeye alıştırd1." ${ }^{49}$ Murad Bey’in burada da asıl vurgusu edebiyat-1 ahlâkiye açısındandır. Çünkü kelimeci anlayışla yazılan şiir, manayı ve ahlâki vurguyu ikinci planda bırakacaktır.

Mîzancı Murad'ın, Edebiyat-ı ahlâkiye adını verdiği anlayışı, şiir değerlendirmesi için de geçerlidir. Şiirde mana kadar ahlâk da önemsenmelidir. Mîzan'ın 33. sayısında Saadet gazetesinde çıkan ahlâki değerlerden uzak olduğunu düşündüğü iki gazeli ve bunları yayınlayan gazeteyi eleştirir. ${ }^{50}$ Zira bu iki şiirin bilhassa makta beyitlerinde Müslümanlığa aykırı düşecek iddialı söylemler bulunmaktadır. Murad Bey gazelleri o kadar İslam’a aykırı görür ki kendilerini değil mealen içerdiği manayı verir ve uyarılarını yapar:

\footnotetext{
“Gençlerimizin ahlâkını 'tehzip hizmetini' deruhde etmek iddiasında bulunan Saadet gazetesi hayat ve fazileti yalnız teskin-i cû ve şehvette görmekte daha devam edecek mi? 'Mey’ ve 'mahbûbu' gazete sütunlarında bâlâya çıkarmaktan - hiç olmazsa mübarek Ramazan'a hürmeten - ihtirâz olunacak zaman daha gelmedi mi? Mânânın itikâda ait olan cihetine dair şakk-1 şefe etmeye cesaret edemiyoruz. Çünkü matbaamızda Saadet matbaasında olduğu misillü ‘mürşid-i mahsus'lar yoktur. Şu kadar ki mezkûr sözleri - velev itirâz için olsun kemâl-i ikrah ile sütunlarımızda dâhil edebildiğimizi beyân ederiz." ${ }^{.1}$
}

46 Halef Nas, “Mizancı Murat ve İsmail Gaspıralı'nın Telif ve Tercüme Eserlere Dair Eleştirel Yaklaşımları”, Yeni Türk Edebiyatı Dergisi 12, (2015): 142.

47 Emil, Mizancı Murad Bey Hayatı ve Eserleri, 386.

48 Zuhal Şirin, Mizan Gazetesi İnceleme, Tahlili Fihrist, Seçme Yazılar (Birinci İstanbul Dönemi 1-159. Sayllar) (Yüksek Lisans Tezi, Fatih Üniversitesi, 2007), 57.

49 Mehmed Murad Mizanc1, "Mebahis-i Edebiyye", Mizan, 5 Kasim 1886b, 39.

50 Şirin, "Mizan Gazetesi İnceleme, Tahlili Fihrist, Seçme Yazılar (Birinci İstanbul Dönemi 1-159. Sayılar)”, 58.

51 Mehmed Murad Mizanc1, "Evrak-1 Havadis”, Mizan, 2 Haziran 1887/33, 276. 
Mîzancı Murad, edebiyat-ı ahlâkiye adını verdiği edebi anlayışının Batı'daki şekillerinin roman ve tiyatro şeklinde verildiğini belirterek edebiyat-1 ahlâkiyeyi yansıtacak roman ve tiyatroların genel özelliklerini sıralamaktadır. Devrin edebiyatçıları, roman ve tiyatrolarda hakkıyla örnek teşkil edebilecek kahramanlık ve vatanperverlikte hüner sahibi toplumsal seçkinler yaratırlar. Murad Bey’e göre eserin olay örgüsü gerçeğe yakın ve tabii olmalıdır. Bununla birlikte toplumsal ahlâk kurallarına ve millî terbiyeye, tab'-1 selime uygun olmalıdır. Eserin gerçeğe uygun olması gereklidir, ancak yeterli değildir. Eserin edebi eser sayılması için mutlaka belagat kural ve usullerine tamamen uygun olması gerekir. Bununla birlikte millî his uyandıracak ibret verecek, günlük hayatı çağrıştıracak, iyi davranışlara özendirip, kötü olanlardan uzaklaştıracak mevzular seçilmelidir. ${ }^{52}$

Mîzancı Murad'ın edebiyat hakkındaki görüşleri siyasi, toplumsal görüşleri ile paralellik arz etmektedir. Ona göre toplumsal ve siyasi yapıda fazlaca yanlışlık ve çarpıklık vardır. Bu konuda edebiyat oldukça önemli bir okul vazifesi görebilir. Bu bakımdan önce edebiyat terbiye edilmelidir. Edebiyatın millî bir karakter kazanarak taklitten kurtulabilmesi ise tenkitçiliğin gelişmesine bağlıdır. Murad Bey’in tenkit anlayışı edebiyat anlayışı ile paralellik arz etmektedir. Tenkidî görüşlerini teorik ve pratik olarak dile getirmiştir. ${ }^{53}$ Mîzan gazetesindeki kimi yazılarında ve özellikle "Mebâhis-i Edebiye" adlı makalesinde edebi tenkidin sınırlarını çizmiştir. "Üdebamızın Numune-i İmtisalleri” makalelerinde ise nazari fikirlerini devrin önemli eserlerini değerlendirerek pratiğe dönüştürmüştür. Ona göre, şiir ve edebiyat estetik ve zevk üzerine inşa olunur bu yüzden gelişimi ve güçlenmesi ciddi tenkidin önemsenmesi ile mümkün olacaktır. ${ }^{54}$

Mîzancı Murad, tenkit hakkındaki görüşlerini sıraladıktan ve edebiyatımızın tenkit geçmişini ele aldıktan sonra edebiyat-ı ahlâkiye adı altında değerlendirmeye değer sınırlı sayıdaki millî eserimizi tenkit bilimi yöntemleri ile ele alarak değerlendirmeler yapmıştır. Roman ve tiyatro türünde neşredilen eserlerimizde edebi kural ve yöntemlerin ne kadar uygulanabildiğini ve edebi değerlerinin ne derecede olduğunu tetkik için Kemal, Ekrem, Hamid, Beyler ve Naci ve Ahmed Midhat Efendilerin meşhur eserlerini değerlendirmiştir. Bunu yapma gayesi ise "bizde metruk bulunan "usul-i tenkit" fennine hizmet edebilmekten ibarettir." Murad Bey bunun için gerekli donanımın kendisinde olmadığını ancak millî edebiyat düşüncesinin rehberi olarak gördüğü tenkit yöntemi hakkında bilgi sahibi kişilerin susmayı tercih etmelerinden dolayı boş kalan edebiyat meydanının fikirleri körelten sessizliğini bozmaktan geri duramamaktadır. ${ }^{55}$

Murad Bey, Namık Kemal'in Silistre tiyatrosunu tenkitle başlar. Bu tiyatro, şöhreti Avrupa'ya kadar ulaşmış millî bir eserimizdir. Ancak Murad Bey, Avrupalılara bir hüküm verdirmeden önce bizim tetkik etmemizi yerinde bulur. Ona göre piyes, millî karakterimize daha uygun olan yeni edebiyat tarzında yazılmış ilk millî eserimiz olduğu için bu kadar hüsn-i kabul görmüştür. Murad Bey eserin halk nezdindeki itibarını ve kıymetini teslim ettikten sonra fenn-i

52 Mizanc1, "Üdebamızın Numune-i İmtisalleri”, 381.

53 Emil, Mizancı Murad Bey Hayatı ve Eserleri, 388.

54 Mehmed Murad Mizanc1, "Mebahis-i Edebiyye", Mizan, 4 Kasım 1886a, 29.

55 Mizanc1, "Üdebamızın Numune-i İmtisalleri”, 381. 
tenkit usulünce tarafsız eleştiriye geçer. “Acaba eser-i mezkûr fenn-i tenkit usulüne tatbiken bi-tarafane muhakeme olunursa o kadar şöhrete şâyân görülebilecek midir? Bir edebi eserden matlûb olan hüsn-i tesir-i umumi cihetiyle evet şayandır. Fakat bi-taraf bir münekkidin bir hayli nakısalar bulabileceği de bî-iştibahtır." ${ }^{56}$

Yazar, incelemeye başladığı eserin öncelikle zemininin pek basit olduğunu vurgulayarak konuyu kısaca özetlemektedir. Yapı, üslup ve tipler açısından kusurlu bulmuştur. ${ }^{57}$ Murad Bey’in bir diğer dikkati de eserde "âsâr-1 mükemmelede en mühim mevki tutan "dram entrikası"nın olmayışıdır. "Hâlbuki müellif eserini âsâr-1 edebiyede en ziyade tehzib-i ahlâka yardımı bulunan bu cihetten çıplak bırakmayabilirdi." Murad Bey tenkidinin burasında piyesin kurgusuna nasıl dram entrikası ilave edileceğine önek verir. Bununla birlikte eserin, sanat-1 maneviyeyi edebiye yönünden medeni ülkelerin ileri gelenlerince dikkate değer bulunabileceğine de şüpheyle bakar. Çünkü eser her ne kadar yeni tarzda kaleme alınmış olsa da hissi derinlikten yoksundur. Eserin ifade yeteneği duyguların tahriki için kâfidir, ancak eser bittikten sonra düşündürecek fikrî mütalaa etkisinden yoksundur.

Murad Bey, konu mütalaasının ardından "kabul-i amme önüne numune-i imtisal olarak vaz olunan eşhasa ayrı ayrı nazar” ederek değerlendirir. İlk olarak Zekiye Hanımı eleştirir. Zekiye Hanım, bir görüşte gönül verdiği sevgilisini düşünmektedir. Murad Bey ilk görüşte âşık olma hususunu üdebamızın münasebetsiz adetlerinden biri olarak görür. Ancak bu durum okuyucuya abes gelmez. Zekiye Hanım, okumuş ve etrafındakilere benzeyen biri değildir. Bu bakımdan Zekiye'nin bu "hafiflik"i göze batmamaktadır. Dahası göze batmayan bir başka husus, Zekiye'nin bulunduğu devir ve memleketin imkânlarının çok üstünde olan bilgi seviyesidir. Murad Bey'in Zekiye'ye bir başka eleştirisi ahlâkını ve namusunu ispat yolunda davranmamasıdır. İslam Bey'in pencereden içeri girme kabahatine karşılık gösterdiği davranışı ahlâka uygun bulmuyor: "Âdâb-1 memlekete, riayet ve nezakete namus ve haysiyete gayr-1 muvafik olan bu harekete karşı Zekiye Hanım kibar ve namuslu bir kız olduğunu göstermek ve vazife-i namusun en şiddetli aşk ve muhabbete bile galip olduğunu ispat eylemek için mütecâsiri def' etmeğe muktedir olamıyor." 58 Murad Bey, Zekiye karakterinin birinci perdede kızlarımıza bir numune-i imtisal olabileceğini kabul eder ama asker kılığında cepheye giden Zekiye'yi âdaba, milliyetimize uygun olmayan yabancı bir cisim olarak tabir eder ve bu yüzden de reddeder. ${ }^{59}$ Değerlendirmeye tabi tutulan bir diğer karakter eserin başkahramanı İslam Bey'dir. İslam Bey'in sahneye ilk çıkışı oldukça menfi bir tarzdadır. Bu da seyirci için olumsuz intiba yaratır. Kendisini davet etmeyen Müslüman bir kızın odasını sessizce önce dinleyip sonra içeri girmesi "şayan-1 takbih"dir. ${ }^{60}$ Tanpınar Murad Bey'in bu eleştirisini yersiz bulur. Namık Kemal'in eserini Batı' daki şekillerine yaklaştırmak için bu yolu tercih ettiğini vurgulamaktadır: "Murad

56 Mizanc1, "Üdebamızın Numune-i İmtisalleri", 384.

57 Emil, "Mizancı Murad Bey’in Edebiyat Ve Tenkide Dair Görüşleri”, 128.

58 Mizanc1, "Üdebamızın Numune-i İmtisalleri”, 386.

59 Mizanc1, "Üdebamızın Numune-i İmtisalleri", 388.

60 Mizanc1, "Üdebamızın Numune-i İmtisalleri", 390. 
Bey acelesinden "Romeo ve Juliet"in balkon sahnesini unutmuştu. Hakikatte âdab-1 İslamiye müsaade etseydi Namık Kemal kahramanlarını balkondan konuştururdu". ${ }^{61}$ Oysa Murad Bey, eserin Avrupa asarını taklit boyutundan habersiz değildir ve bu konuyu da aydınlatmaktadır: "Maksat Avrupa asarına taklitten ibaret ise, faydasız bir zahmet olduğunu beyandan başka bir diyeceğimiz yoktur. Öyle olmayıp da bir numune-i imtisal makamında efrad-1 millete gösteriliyor ise merduttur." ${ }^{62}$ Murad Bey durumun sosyolojik açıdan da imkânsızlığını ifade eder. Devrin toplumsal yapısı bir görüşte aşka müsait değildir. Oysa Zekiye'yi tahlil ederken onun İslam'a olan meylini tabii görmüş iken İslam Bey'de bu durumu takbih etmektedir. Şöyle ki: “İslam Bey’in bir görüşte Zekiye Hanım'a alaka etmesi merduttur. Hanım bâligadır. Binaenaleyh mesturedir. Taaşşuk edilecek surette görünemez. Görünürse rrz ve edebi bozuk demektir. İslam Bey için küfüv olamaz." ${ }^{63}$ Esere o günün toplumsal normları açısından bakıldığında başka toplumdan transfer edilen edebi türün bize intibakındaki aksaklık hemen göze çarpmaktadır. Murad Bey, iki kahramanın psikolojik ve sosyal durumlarını, aralarındaki hissi ve aktif iletişimin eserin kurgusunda yarattığı aksaklıkları ortaya koymuş, bize, numune-i imtisal olarak sunulmak istenen karakterlerin aslında numune-i imtisal olup olamayacaklarını millî ve İslâmi âdap ve ahlâki edebiyat açısından değerlendirmiştir. ${ }^{64}$ Bütün bu pencerelerden eseri son olarak şu cümlelerle değerlendirir:

\footnotetext{
"Yabancı erkeğin pencereden odasına girdiğini görünce ibtida komşusunun ne diyeceğini düşünen veya erkek elbisesiyle sevgilisinin arkasına düşüp aylarca ordu içinde yatıp kalkan küçük hanımefendiler ile kimsesiz bir namuslu kızın odasına davetsiz olarak pencereden uğrayan ve sonra mukaddesat-1 İslamiye'den bulunan cananını ordu içinde tutmak ile iktifa etmeyip, yüzde doksan dokuz o cananı din ve devlet düşmanına esir vermek ve kendisi için ölmek ihtimali aşikâr bulunan düşman ordugâhına kadar sürükleyen beyefendileri, ümmet-i muhtereme gençleri için numune-i imtisal makamında kabulde, âdâb-1 İslâmiye'ye hürmeten tereddüt eder isek - ümit ederiz ki - hareketimiz müellifin-i kiram hazerâtı indlerinde mazur tutulur." ${ }^{65}$
}

"Silistre" tenkidi oldukça ilgi görmesine karşın bu eserin tenkit edilmesini eleştirenler de olmuştur. Bunlardan T. E. İmzalı bir mektuba gazetesinde yer veren Mehmet Murad daha sonra tenkidini kalp ve haysiyet sahibi insanlarca meşru ve kavi bir sebebe mebni, mecburen yarıda bırakmıştır. Sebep olarak Murad Bey, Namık Kemal'in edebi sohbete dâhil olamayacağını belirtir. Çünkü bu vakitte Namık Kemal Sakız'da sürgündedir. Tenkitlere de Ebuzziya aracılığıyla cevap verebilmektedir. Bu durumda tenkide devam etmenin elleri bağlı birine tecavüz-kârane hücuma benzeyeceği söylenmiştir. ${ }^{66}$

61 Ahmet Hamdi Tanpınar, On Dokuzuncu Asır Türk Edebiyatı Tarihi (İstanbul: Çağlayan Kitabevi, 1997$), 380$.

62 Mizanc1, "Üdebamızın Numune-i İmtisalleri", 390.

63 Mizanc1, "Üdebamızın Numune-i İmtisalleri”, 390.

64 Emil, Mizancı Murad Bey Hayatı ve Eserleri, 396.

65 Mizanc1, "Üdebamızın Numune-i İmtisalleri", 394.

66 Ayşegül Ergişi, Mizan Gazetesi İnceleme, Tahlili Fihrist, Seçme Yazılar (Kahire Dönemi 159-184; Paris-Cenevre Dönemi 1-29; II. Ístanbul Dönemi 1-135 Sayılar) (Yüksek Lisans Tezi, Fatih Üniversitesi Sosyal Bilimler Enstitüsü, 2007), 62 . 
Murad Bey, Silistre'den sonra Ekrem Bey'in Vuslat piyesini değerlendirmiştir. Aslında eseri beğenmiştir. Buradaki eleştirileri de ahlâki edebiyat çerçevesinde ve yukarıda bahsi geçen usul etrafında şekillenmiştir. Eser, dram entrikası bağlamında yine kusurlu bulunmakta, ahlâki endişeler etrafında tenkit edilmektedir. ${ }^{67}$ Murad Bey, üç perdelik bu piyesi daha geniş ve ayrıntılı bir şekilde on makalelik bir seri halinde tahlil etmiştir. "Ayrıca, eserdeki bazı durumlar ve şahıslar vesilesiyle şahsi fikirler ileri sürmesi, ahlâki ve ictimâi yaralara parmak basması Vuslat tenkidine birinciden çok farklı bir karakter verir." ${ }^{68}$ Murad Bey, eserde iki yön arar icat ve tasvir. İcat hayal, tasvir ise tecrübe ve deney ürünüdür. İcat müellifin hayal gücünün eseri olduğundan eseri kontrolü yazardadır. Ona göre Vuslat'ta icat hiç yoktur. Konu olarak ise Silistre' den daha basittir. Ancak "kıymet-i hakikiye-i edebiye itibariyle müellifi tarafindan ret olunan Vuslat eseri, şöhreti cihana akseylemiş olan Silistre'ye faiktir." ${ }^{69}$ Parlak, emsalsiz âli Silistre'yi Vuslat'a tercih etmek büyük cürettir. Ancak Murat Bey iddiasında israrcıdır. Ona göre Silistre, eskimiş bir tahta üzerine mahir bir usta tarafından halis yaldızdan oyulmuş latif bir resimdir. Tamir ve ıslahı güçtür. Bu bakımdan bir dâhinin eseri olarak saklanmalıdır. Vuslat ise toza toprağa karışmış bir mermer heykeldir. Temizliği güç olmadığ gibi Osmanlı edebiyatının şanı için hatta gereklidir. Demektedir. Murad Bey, Vuslat'ın hak ettiği değeri görebilmesi için biri yüzeysel öbürü esaslı iki öneri sunar. Birincisi eserde işaret de edilen

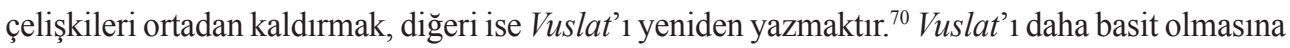
rağmen Silistre' den üstün bulması Murat Bey’in ahlâki edebiyat savunusunun gereğidir. "İcattan önce tasvire değer vermenin gerekliliği de Mîzancı Murat'ın eleştiri anlayışında eserde aradığı ölçülerden biridir. ${ }^{71}$ İcat Yazarın hayali mahsulüdür. Oysa tasvir gerçekliğin yansımasıdır. Murat Bey gerçekçi eleştirel tutumu eserde hayalden ziyade gerçekliğin yansıtılıyor oluşuna değer vermeye yöneliktir.

Murad Bey, “Üdebamızın Numune-i İmtisalleri” başlığıyla neşrettiği tenkit makalelerinde üçüncü olarak Sami Paşazade Sezai’nin Sergüzeşt romanını ele alır. Daha ayrıntılı tenkit etmeği planladığı bu eserin değerlendirmesini bitirememiş, ancak dört makale devam edebilmiştir. ${ }^{72}$ Murad Bey, daha önce belirtmediği halde Sergüzeşt'i tenkit etmeye karar vermesinin iki büyük nedeninden bahsetmektedir. Birincisi gazetenin taze havadis verme gayretidir. Zira Sergüzeşt yeni yayımlanmıştır. Bu durum ona üstünlük hakkı tanımaktadır. Diğer husus, Sergüzeşt yayımlanınca oldukça büyük bir etki yapmıştır. Bu durum hakkında olumlu ya da olumsuz birçok fikir yürütülmesine neden olmuştur. Bu durum Murad Bey’den de fikir beyan etmesi beklentisini doğurmuştur. Murad Bey'in fazla olarak eklediği bir diğer husus da Sergüzeşt 'in konu ve tema olarak Vuslat'in aynisı olmasidir. ${ }^{73}$

67 Nas, "Mizancı Murat ve İsmail Gaspıralı'nın Telif ve Tercüme Eserlere Dair Eleştirel Yaklaşımları", 142.

68 Emil, Mizancı Murad Bey Hayatı ve Eserleri, 396.

69 Mizanc1, "Üdebamızın Numune-i İmtisalleri”, 432.

70 Mizanc1, "Üdebamızın Numune-i İmtisalleri”, 432.

71 Nas, "Mizancı Murat ve İsmail Gaspıralı'nın Telif ve Tercüme Eserlere Dair Eleştirel Yaklaşımları", 148.

72 Emil, Mizancı Murad Bey Hayatı ve Eserleri, 403.

73 Mizanc1, "Üdebamızın Numune-i İmtisalleri”, 434. 
Murad Bey'e göre Sergüzeşt'te de birçok eksiklikler vardır ancak bu noksanlar "mesela Silistre'nin noksanları gibi esasta ve maksat ve mevzua halel verecek surette olmayıp derece-i ehemmiyetleri dûn olan teferruatta olduğu için, eserin aslına nakısa" vermemektedir. Murad Bey, Sergüzeşt' $i$, genç, azimli ve yetenekli bir mimarın henüz tecrübesizken inşa ettiği bir binaya benzetir. Genel olarak Murad Bey, Sergüzeşt eserini konusu itibariyle çok beğenmiş, yazarının maksadını iyi bulmuş hele üzerine alındığı manevi vazifenin yerine getirilişindeki başarısı cihetiyle Sergüzeşt'i emsalsiz bir numune-i imtisal olarak kabul etmiştir. ${ }^{74}$

Görüldüğü gibi Mîzancı Murad'ın edebiyattan en büyük beklentisi eğiticiliği yönündendir. Ancak bu edebiyatın halka ansiklopedik bilgi vermesi demek değildir. Çünkü ona göre kurtuluşun çaresi ahlâklı, dürüst bir seçkinler grubu yetiştirmektir. ${ }^{75}$ Roman ve tiyatrosundaki müspet tipler, hayata karşı dürüstlük ve güzel ahlâkla donanmış bir duruşu olan ideal tiplerdir. $\mathrm{Bu}$ karakterlere eserlerde yer vererek imrendirecek ya da menfi olanlarına iğrendirerek edebiyatın toplum ahlâkına hizmet etmesini sağlayacaktır. Murad Bey, edebiyatın toplum üzerindeki etkisini Batı'daki örneklerinde de gözlemlemiştir. Bu yüzden yazarın hüneri, toplum ahlâkında gerçekleştirebileceği düzeltme etkisi ile doğru orantılı olmalıdır. Hüner, herkesin gözü önünde dururken dikkatten kaçan kötülükleri etkili şekilde ortaya koyarak dikkati üzerine çekmektir; toplumun ahlâki ve örfi kuralları içerisine gizlice girip yerleşmiş olan pürüzleri derleyip "erbab-1 himmetin 1slah eline birakmaktır; makbul olana herkesi imrendirip ona yönlendirmek ve makbul olmayana, kötülüklere karşı nefreti yerleştirerek 'efkâr-ı necibe'yi uyandırmaktır". ${ }^{76}$

Mîzancı Murad, topluma ve geleceğe karşı kendisini mesul hisseden diğer birçok Tanzimat aydınları gibi yazının bütün imkânlarını elinden geldiğince kullanmaya çalışır. Gazete onu amacına en yaklaştıran platform olarak neredeyse ömrünün sonuna kadar en önemli meşgalesi olma özelliğini korur. Murad Bey, yıllarca gazeteden ülkedeki toplumsal, siyasi, ekonomik edebi vs. görebildiği bütün aksaklıkları ve bulabildiği çözüm önerilerini gazete aracılığıyla hatta saraya ulaştırmıştır. Batı edebiyatını da iyi okuyan biri olarak edebi tenkitten de geri durmamış, gazete sayfalarında devrin edebi meselelerini ve eserlerini değerlendirmiş, öneriler sunmuştur. Bunu yaparken oldukça muteber ağızlardan "tenkit ve itirazda bulunmak kolaydır. Hüner öyle bir eseri meydana koymaktır” şeklinde uyarılar da almış bunu sonucu olarak edebi eser neşretmeye koyulmuştur. Tenkit yazılarında ifadesini bulan poetikasının uygulama alanı olarak kurguladığı biri tiyatro diğeri roman türünde olmak üzere iki eser neşretmiştir. Romanının başına "İfade-i Mahsusa" başlığıyla aldığı önsözünde öncelikle bizde romanın durumunu bir cümle ile özetler: "Bizde roman namı pek ucuz olarak alınıp verilmektedir. Beş on seneden beridir, ele alınması caiz olmayan kaba bir muaşaka tasvirleri "millî roman" unvanı altında itibar bularak kemal-i itina ile okunmaktadır."77

74 Mizanc1, "Üdebamızın Numune-i İmtisalleri", 439.

75 Berna Moran, Türk Romanına Eleştirel Bir Bakış I. (İstanbul: İletişim Yayınları, 2007), 20.

76 Mizancı, "Üdebamızın Numune-i İmtisalleri”, 439.

77 Mehmed Murad Mizanc1, "İfade-i Mahsusa", Turfanda mı Yoksa Turfa mı? içinde, haz. Tacettin Şimşek, (Ankara: Akçă̆ Yayınları, 1999b), XIV. 
Murad Bey, Münşilik ve ediblik iddiasında değildir. Ancak kitabette gördüğü eksiklikleri düzeltmek ve esasına uygun gerçekten “millî roman” sıfatını haiz bir eser neşrini amaçladığını romanının önsözünde belirtmektedir. Aynı yazıda, edebi türler içinde millî ve ahlâki faziletlere tesiri şüphesiz olan romanın ihmal edilmiş olmasından yakınarak içinde yaşamakla müftehir olduğumuz asr-1 terakkiyat-hasr-1 mülükanede her şey kesb-i kemal ettiği halde fazail-i ahlâkiyeye tesir-i küllisi musaddak ve mertebe-i edebiyeyi millîyeyi musavvir olan roman kısmının, erbab-1 kalemin itinası haricinde kalması nazar-1 dikkate çarpacak ahvalden bulunduğu cihetle, "karınca kaderince" fehvasına binaen vüs' ve iktidar dâhilinde ifa-y1 vazife ediyorum." ${ }^{78}$ demektedir.

Murad Bey'in romanı, gazete yazıları, siyasi ve edebi görüşleri üzerine çok sayıda çalışma ve araştırma yapılmış olmasına karşın, Tencere Yuvarlandı Kapağını Buldu adlı tiyatro eseri Osmanlı Türkçesinden günümüz Türkçesine çevrilmediği gibi hakkında da eserin künyesi dışında bilgi veren çalışma da bulunmamaktadır.

\section{Tencere Yuvarlandı Kapağını Buldu}

Tencere Yuvarlandı Kapă̆ını Buldu Mîzancı Murad Bey'in tek tiyatro eseridir. 1326 yılında İstanbul'da neşredilen eser, dört perdelik bir komedidir. Yerli mizaçlı kahramanlara yabancı isimler verilmiş olması eserin dikkat çeken özelliklerinden biridir. Her ne kadar bu dönem eserlerde yabancı kahramanlara rastlanabilmekteyse de bu eserdeki kahramanların yaşam biçiminin yerli oluşu bu eseri bu açıdan yeni yapar. Bu durum yazarın en önemli hassasiyeti olan ahlâki edebiyat konusunda gelebilecek eleştirileri engellemek için olmalıdır. İslam Bey'in Zekiye'nin odasına girmesini eleştirdiği gibi kendisi de benzeri bir şekilde eleştirilebilirdi. Ancak yazar sonraki yazılarında da bu konuda herhangi bir bilgi vermemektedir. Yazarın tenkitlerinde en çok değindiği nokta eser kahramanlarının millî ahlâk, adap ve İslami kurallara aykırı davranışlarıdır. Evliliğin konu edildiği bir eserde kadın ve erkeklerin bir araya gelmeleri veya gayrimeşru sayılacak durumlardan bahsedilmesi yazarın amacına ulaşması için gereklidir. Oysa İslami kurallarla yaşayan kahramanların eserdeki çatışma yaratacak durumları yaşayabilmeleri gerçekliğe aykırı olacaktır. Murad Bey’i tam da eleştirdiği noktada okların hedefi haline getirebilecektir. Tiyatrosundaki bu yaklaşım, Murad Bey'in poetik anlayışına oldukça uygundur. Murad Bey, edebiyatçı kimliğinden ziyade siyasetçi ve gazeteci ve fikir adamı kimliği ile tanınır. Edebiyatı toplumun yönlendirilmesi, ahlâki düzelmenin sağlanmasında çok önemli bir araç olarak görmektedir. Bu bakımdan öncelikle Mizan gazetesindeki kimi yazılarında seri makaleler halinde edebiyat görüşünden bahsetmiş ve devrinin şöhretli yazarların meşhur eserlerini değerlendirmiştir. Bu eleştirilerinde en çok değindiği ise "edebiyat-1 ahlâkiye” adını verdiği anlayıştır. Edebiyat mevcut ahlâk anlayışımızı, millî değerlerimizi muhafaza etmeli, yanlışlarımızı düzeltmeli ve hatta ilerlememizi sağlamalıdır. Bu bakımdan Murad Bey’in yazdığ1 tek tiyatro eserine toplumun temelini oluşturan aile kurumunu ve bu kurumun bina edilişindeki yanlış anlayışları işlemesi manidardır.

78 Mizanc1, "İfade-i Mahsusa", XV. 
Murad Bey'in tek romanı olan Turfanda mı Turfa $m \iota$ adlı eseri de tezli bir romandır. Murad Bey, bu romanda kendisiyle özdeşleştirdiği Mansur adındaki kahramanına ideal bir yaşam çizer. Mansur Bey'in yaptıkları ve söyledikleri Murad Bey'in yaşam biçimi ve hayat felsefesi ile oldukça örtüşmektedir. Hatta romanın ilk sayfalarındaki İstanbul'a ilk defa gelen Mansur'un hissettiklerinin bizzat kendisinin ilk İstanbul izlenimleri olduğunu hatıralarında belirtmiştir. Bu eserde de Vayan adlı karakter Mansur Bey ve dolayısıyla Murad Bey’le özdeş karakterdir demek yerinde olacaktır. Murad Bey'in tiyatrosunda da romanında olduğu gibi karakterleri müspet ve menfi karakterler olarak ayırmak mümkündür. Bu ayrım, henüz daha tiyatronun baş kısmında karakterlerin tanıtıldığı bölümden anlaşılmaktadır. Yazar kahramanlarını tanıtırken taraf tutar. Kullandığı "Vazifeşinas, boş kafalı, ciddi ağırbaşlı vs." gibi ifadeler yazarın kahramanlarına karşı tutumunu açıkça göstermektedir. Romanında olduğu gibi kendisi için müspet olan şahısları korumuştur. Murad Bey’in müspet karakterleri şahsi çalışmaya ahlâk irade ve kişiliğe önem veren kişilerdir. Menfi tipler ise mevki ve servet düşkünü bunu elde etmek için her yolu mübah gören ve ahlâki hassasiyetleri hiçe sayan kimselerdir.

Bu piyesin en dikkat çeken yönlerinden biri de A. Hamid, R. Ekrem ve N. Kemal piyeslerindeki romantik ve santimantal unsurların bu piyeste hiç yer almamış olmasıdır. Olumlu ya da olumsuz karakterlerin tamamı hayattaki öncelikleri ve ne yapacakları konusunda net fikir sahibidirler. Gerçekçidirler. Düşünceleri net ve sabittir. ${ }^{79}$

Eserin bir diğer hususiyeti ise ismi ile ilgilidir. Turfanda mı Yoksa Turfa mı romanının önsözünde yaptığı açıklamadan yazarın romanın adının verdiği mesaja hassasiyet gösterdiğini anlamaktayız. Romanı millî roman örneği vermek gayesi ile ele almıştı. Muhtemelen piyesi yazmaktaki amacı da millî ve ahlâki bir piyes vücuda getirmektir. Murad Bey, atasözlerinin bir milletin medeni seviyesini göstermede en önemli malzeme ve en kestirme yol olarak görmektedir. Bu bakımdan eserini bir Türk deyimi ile adlandırmış olması mânidardır. Bu durum şahıs isimlerini ecnebi seçtiği eserin millîliğini arttırmaktadır. Tencere yuvarlandı kapağını buldu deyimi özellikle evlilik konusunda birbirinin dengini bulan kişiler için kullanılır. $\mathrm{Bu}$ isim her ne kadar millî bir çağrışımla yazarın amacına hizmet etse de eserin sonu hakkında fikir verdiği için esere ilişkin merak unsurunu akim bırakmıştır.

Eser kahramanlarının isimleri her ne kadar yabancı isimlerden seçilmiş ise de yaşayış ve hayata bakış açıları hatta inançları yerlidir. Örneğin Madam Loan’ın kız çocuğu yetiştirme tarzı, kızların sosyal hayattaki statülerine bakışı bir Anadolu annesiyle özdeştir. Daha ilk sözlerinde biz Madam Loan’ın tipik bir Türk kadınının toplumsal bakışını yansıtan, klişe söylemlerinden "Kız kısmı nişanlısını gelin odasında görüp öğrenir” cümlesini tekrarladığını görürüz. Bu cümle ve daha nice söylemler bize adı Madam Loan olan bir Anadolu annesi çelişkisini yaşatır. Piyes'in kişileri yabancıdır. Ve olay Paris’te geçmektedir. Paris’te Fransız bir ailenin karşılaştı̆̆ı sorunlara Türk adet, örf ve ananesine, dahası İslami yaşayışa uygun olarak verdikleri tepkiler ve buldukları çözümler okuyucu/seyircide algı yanılması yaşatır.

79 Emil, Mizancı Murad Bey Hayatı ve Eserleri, 454. 
Piyes'in dili devrine göre değerlendirildiğinde dikkat çekici nispette bugünkü Türkçeye yakın ve oldukça sade bir yapıya sahip olduğu görülür. Yazarın dili kullanma üslubu şahısların karakterlerine uygun olarak değişebilmektedir. Bu durum karakterlerin tavrını netleştirir. Okuyucu ya da dinleyicinin aklında herhangi bir dilemma oluşmasına müsaade etmeyecektir. "Lüzumsuz hiçbir kelime, üsluba ait hiçbir tavsif teferruatı araya sokulmamıştır.". ${ }^{80}$ Bununla birlikte yazarın eserin başında belirttiği şahısların yabancı mevzunun yerli oluşu hususiyeti eserin dilinde de ufak bir şaşkınlık yaratır. İsimlerinden ve söylemlerinden Fransa'da yaşadıklarını anladığımız kimselerin Osmanlı toplumu ahlâki, toplumsal yapısına sahip bireylere has ifadeler kullanması, çelişkili bir durum yaratır. Piyes boyunca, Batılılarda rastlanılan tarzda baskın ve adı Natalie olan bir kadının Osmanlılara has geleneksel toplumsal normları dayattığı, geleneksel ve dini klişe söylemleri tekrarlaması okuyucu/seyircide sürekli bir bilinç değişsimi yaşatır.

Eserin konusu o dönemin birçok tiyatrosuna konu olan görücü usulü evliliklerdir. Ancak Murad Bey bu konuya, Şinasi’nin Şair Evlenmesi'nden farklı bir bakış açısı getirir. Mîzancı Murad, konu olarak evliliği seçmiş ise de vermek istediği mesaj farklıdır. Şinasi, birbirini görmeden yapılan evliliklerin yaratacağı problemlere dikkat çekerken Murad Bey, toplumsal ahlâk, millî ve manevi değerler ölçüt alınmadan hatta çıkar için yapılacak evliliklerin yanlışlığına dikkat çekmek istemektedir. Ancak her iki eserin ortak yanı toplumsal yozlaşmalara dikkat çekmeleri ve olay sonunda konunun tatlıya bağlanmasıdır. Şair Evlenmesi, mesajını güldürü unsuruna ağırlık vererek vermeye çalışır. Ancak Tencere Yuvarlandı Kapağını Buldu'da komedi unsuru oldukça azdır. Monologlar ve diyaloglar vasıtasıyla yazar her firsatta edebiyatı ahlâka hizmet ettirmeye çalışır.

Oyunun olay örgüsü özetle şöyledir. Mösyö ve Madam Loan Matmazel Mari’nin anne ve babasıdır. Matmazel için Ernest Lömon adında bir talip vardır. Genç bir mirasyedi olan bu genç, işyerindeki amirinin genç kadınlara yani çalışanlarının eşlerine olan eğilimini bildiğinden, yükselme arzusuyla evlenmeyi düşünmektedir. Mari'inin Ernest'le evlenmesini annesi ve teyzesi kızı Sofi dışında uygun bulan yoktur. Sağduyulu bir adam olan babası ise kızı için Vayan adındaki bir mimarı uygun bulmaktadır. Ancak Vayan'ın babası ile işten kaynaklanan bir kırgınlıkları vardır. Piyesin sonunda bu anlaşmazlık da giderilir. Sonunda herkes dengi olan şahısla evlenme kararı alır.

Oyunun kişi kadrosu çok kalabalık olmamakla birlikte kompleks ya da şaşırtacak bir kişi de yoktur. Bu durum oyun sonunun bizi şaşırtmamasına neden olur. Kişi kadrosu şöyledir:

Madam Loan: Oyunun başında "boş kafalı, kırkbeş yaşında olduğu halde gençlik davasında, kendini çok beğenmiş" olarak tanıtılan Madam Loan oyunun sonuna kadar en aktif karakterlerden biridir. Oldukça hırslı, makam ve para sevdalısı bir hanımdır. Her ne kadar kişilerin tanıtıldığı bölümde gençlik davasında deniliyorsa da oyun boyunca biz bu türlü bir ima ile karşılaşamıyoruz. Madam Loan oldukça baskın bir karakterdir. Eşi ve kızı üzerinde hâkim bir söz hakkına sahiptir. Madam Loan davranış modeli olarak bir Anadolu kadını modeli ise de bu hâkim tavrıyla Batılı

80 Emil, Mizancı Murad Bey Hayatı ve Eserleri, 454. 
kadın tipine çok yaklaşır. Madam Loan'ın evlilik için gerekli gördüğü şartlar daha maddiyatçı ve pragmatisttir. Ona göre evlenilecek “erkek dediğin itibarlı olur. Resmi günlerde kılıç kuşanıp sırmalı esbablarını giyer." "\$1 Oysa Mari ve babası, evlilik için en son düşünülmesi gerekenin maddi varlık ve makam olduğunu savunmaktadır. Zaten piyesin en önemli çatışması da bu mevzu üzerinde teşekkül eder. Tanzimat dönemi eserlerindeki çoğu kadın gibi Madam’ın da en önemli eksikliği iyi bir tahsil görmemiş olmaktır. Bu yüzden okumayı, sorgulamayı seven kızını kendisine yabancı görmektedir. Madam'ı bu yönüyle de Mösyö Loan'1n cümlelerinden tanıyoruz: "Validen pekiyi bir kadındır. Ben de kendisini çok severim. Lakin tahsil görmemiş, malumatı validesinin yanında gördüğü cüzi şeylere münhasır kalmıştır. Validesini pek mükemmel bildiği için fazla bir şey bilmek ve öğrenmek istemiyor. İstediğin kadar hikmetten, mantıktan bahset, kulak bile vermez, dediğini tekrar eder." "82 Buradan hareketle diyebiliriz ki Madam'ın Mari'nin kendisine itaatkâr olması yolundaki ısrarı ve beklentisi de kendisinin annesine olan tutumundan kaynaklanmaktadır. Madam Mari’yi istediği gibi yetiştirememiştir. Bunun en önemli nedenleri ise mösyö ve mekteptir. Madam okula hiç gitmemiştir. Ve gerek de duymamakta, eksikliğini hissetmemektedir. Hatta mektep yolunu öğrenmemiş olduğuna şükretmektedir: "Ben elhamdülillah öyle yeni icatlar görmedim. Mektep kapısının nasıl olduğunun şükür öğrenmedim. Bununla beraber hanımlığıma, kadınlığıma halel gelmedi. Mari’yi kendim gibi bir kadın etmek sana kâfi değil midir? Şimdi sayende girdiği kalıp ve kıyafete bak da ibret al. ${ }^{93}$ Aslında Madam, tek kızının yetiştirilmesi konusundaki salahiyetin kendisine bırakılmamış olmasından dolayı kırgındır. Bunun sebebini kendi yetersizliğinde görüp hırçınlaşır. Ancak yine de Mari'nin bu halde dile düşmemesini kendi himayesinde oluşuna bağlar. Bu bakımdan onun en önemli tatmin kaynağı yeğeni Sofi'dir. Sofi, tam da onun istediği nitelikleri haiz bir genç kızdır. Bu yüzden Sofi’yi kimi zaman ve özellikle oyunun sonlarında kendi kızına tercih etmektedir.

Madam Loan, bu kadar baskın bir karakter olmasına rağmen kızı üzerinde etkili olan karakter Mösyö Loan'dır. Bu durum piyesin önemli çelişkilerinden biridir. Zira Madam Loan'1 piyesin sonuna kadar kimse inandığının aksine bir şeye ikna edememişken Mari’nin bu kadar muhalif bir karakterde yetişmiş olması ilginç bir ayrıntıdır. Bu durum yazarın da dikkatini çekmiş olmalı ki Madam, bu durumun sorumlusu olarak eşini gösterir: "Zaten her derdime sebep sen değil misin? Mari'yi istediğim gibi terbiye edemedim ise sebep senin fesadın ve batıl iddiaların değil midir? Evimizde her ne noksan görüldü ise hep senin eserin değil midir? Mari pekiyi bir kızdır. Herkes de bana benzetiyor. İşin içinde senin münasebetsizliklerin olmasa idi, tıpkı benim gibi olacaktı. Her şeyime müdahale ederek çığırdan çıkarıyorsun." ${ }^{84}$ Mari üzerinde asıl etkili olan babasıdır. Madam bu durumun farkındadır ve hoşlanmamaktadır. Çünkü bir kız çocuğu üzerinde en müessir kişi annesi olmalıdır. Madam Loan bu konuda toplumun büyük

81 Mizancı, Mehmed Murad. Tencere Yuvarlandı Kapağını Buldu, (İstanbul: Dersaadet, 1908), 6.

82 Mizancı, Tencere Yuvarlandı Kapağını Buldu, 26

83 Mizancı, Tencere Yuvarlandı Kapağını Buldu, 15.

84 Mizancı, Tencere Yuvarlandı Kapağını Buldu, 14. 
çoğunluğu gibi düşünür ancak Mari yaşıtlarından farklı bir mizaca sahiptir. Madam, Mari’ye istediğini kabul ettirebilmek için babasının etkisini azaltmayı dener. Onunla konuşacağı zaman Mösyö'yü ya dışarı gitmesi ya da kesinlikle konuşmaması konusunda her defasında uyarır. Madam, bütün radikal tavrına ve baskın duruşuna rağmen oyun sonunda Mari için beklentisini gerçekleştiremez. Ancak yazar, eseri onun da gönlünce bir sonla sonlandırır.

Mösyö Loan: Mösyö Loan ilk olarak "Daire muhasebecisi, elli yaşında, mahviyetli ve vazifeşinas" biri olarak tanıtılır. Bu tanımdan Mösyönün de müsbet tarafta olduğu rahatlıkla anlaşılabilmektedir. Piyes boyunca serinkanlı ve tecrübeli insanlara has bir sükûnetle olaylara yaklaşan biri olarak karşımıza çıkmaktadır. Madam'ın fevri ve aksi davranışları karşısında serinkanlı ve olgun yaklaşım sergiler. Piyes boyunca Madam'ın bütün kışkırtmalarına karşın hiç sinirli görmeyiz. İnsanları iyi tahlil edebilen biridir. Babası yüzünden işinden olduğu düşüncesi hâkim olmasına karşın Vayan hakkında, kızıyla evlenmesini isteyecek kadar, olumlu düşünce beslemektedir.

Mösyö Loan, mesleğinin icrasında gösterdiği faziletli duruş açısından da Murad Bey’in ideal tipine uygundur. Piyesin başlarında Mösyö Loan, işten el çektirilmiş bir muhasebeci olarak çıkar karşımıza. Daha ilk perdede Madam'ın sözlerinden Vayan'ın babasının, Mösyö Loan'ın işi konusunda olumsuz bir girişiminin olduğunu anlamaktayız. "Sen hala şu Vayan çapkınını düşünüyorsun. Mademki onu o kadar çok istiyorsun işini öyle yüzüne gözüne niye bulaştırdın? Herkes çalar çırpar ama Vayan çapkınının babası gibi rast gelen müfettişin eline ipin uçlarını vermez." ${ }^{85}$ Bu replikten Mösyö Loan'ın bütün olanlara rağmen kızı için uygun aday olarak Vayan'1 düşündüğünü de anlamaktayız. İkinci perdenin sonunda Mösyö Loan'ın işten el çektirilmesinin asıl nedeni ve yanlış anlamanın nasıl ortadan kalktığı Vayan'ın babasının gönderdiği mektuptan anlaşılmaktadır. Mösyö Loan, muhasebeci olarak görev yaptığı yerde çalışanlardan büyük bir aileye mensup bir gencin irtikâbını fark eder. Bu gence, aldığı paraları yerine koymak için mühlet ve bundan sonra istifa şartı koyarak şimdilik ses çıkarmayacağını belirtir. Ancak bu mühlet dolmadan Vayan'ın babasının içinde olduğu teftiş gerçekleşir. Bunun sonucunda Mösyö Loan mesuliyeti üzerine alarak gencin adını vermez. Suçlu duruma düşer. Vayan'a babasının gönderdiği mektupta irtikâp suçunu işleyen gencin babasının işi anlayarak itiraf ettiğgi ve paraları getirdiği yazılıdır. Böylece Mösyö Loan aklanmış olur. Vayan ve Mari'nin izdivacı için Madam'ın gördüğü engellerden biri ortadan kalkmış olur.

Mösyö Loan da kızı gibi Ernest Lömon'u uygun aday olarak görmemektedir. Ancak bunu karısına söylememekte sabırla beklemektedir. Son raddede eğer Madam kızının istememesine rağmen 1srarcı olursa müdahale etme niyetindedir. Bu durum, onu bu ve başka konularda karısı karşısında pasif olarak gösterir. Ernest'le ilk karşılaşmalarında onu sertçe uyarması üzerine Ernest Mösyö Loan hakkında etraftaki hâkim kanıyı dile getirir, "Bizim kaim peder hazretleri sertçe bir şey! Bana ise madamın fistanına yapışmış bir paçavra parçası dediler." ${ }^{\text {86 }}$

85 Mizancı, Tencere Yuvarlandı Kapağını Buldu, 6.

86 Mizancı, Tencere Yuvarlandı Kapağını Buldu, 57. 
Vayan: Piyes'in en ideal, en müspet tipidir. Bu karakter, yazarın Turfanda mı Yoksa Turfa mı? Romanındaki Mansur Bey'in karakter ve hayat anlayışı açısından bire bir aynısıdır. Erdemli ve yükssek ahlâk sahibi bir mimardır. Eserin başında Vayan, "yirmi sekiz yaşında, gayyur, metin, ulviyete âşık" biri olarak tanıtılır. Eserin ana kahramanlarından biri olan Vayan, küçük yaştan beri tanıdığı Mari’ye âşıktır. Ancak onun kendisi hakkındaki hislerinden emin değildir. Bu yüzden Ernest'in Mari ile evlenme düşüncesine oldukça üzülür. Ancak dürüst biri olduğu için Ernest'in evlenmeyi düşündüğü Mari hakkındaki sorularına olumlu cevap verir. Piyesin başında Vayan'ı Madam'ın ifadeleri ile de tanıtılmaktadır. Her ne kadar Madam bu ifadeleri menfi tarzda söylüyor ise de Madam bize menfi karakter olarak tanıtılmış olduğundan onun menfi sözleri, müspet tarzda algılanmaktadır. "Herif babasının hazırladığı memuriyeti reddetmiş. Mimarlık ve mühendislikle geçinecekmiş. Ne yapayım öyle formasız nişansız erkeği." ${ }^{87}$ İkinci perdenin hemen başında Vayan bir iç monologla bize kendisini tanıtır. Bugüne kadar istediği her şeye beklentisinin üzerinde sahip olmuştur. İstediği, kimsenin minneti altında kalmadan geçimini temindir. Oysa bugün kazandığı yüz kişiyi geçindirecek kadardır, gittikçe de ilerlemektedir. Sıhhati, itibarı ve toplumdaki yeri çok iyi durumdadır. Girdiği bütün yarışmalarda birincilikler almıştır ve şehre resmi mimar olmuştur. Ancak mutsuzdur. Çünkü sevdiği tarafından sevilip sevilmediğinden emin değildir.

Piyes boyunca Murad Bey'in fikirsel yaklaşımı Vayan vasıtasıyla keşfedilir. Bu bakımdan Vayan Yazarın piyesteki temsilcisidir demek yanlış olmayacaktır. Vayan, paraya tamah etmeyen biridir. Bu piyes boyunca birkaç vasıta ile aktarılır. Bunlardan biri eski kötü yaşantısını terk ederek köye yerleşme kararı alan Adel'le Ernest arasındaki sözleşme feshinden kaynaklanan ödemeyi üstlenmesidir. Bir diğerini Ernest Adel'e anlatır. İki tarafın bir alışverişte anlaşmasını malı bir taraftan satın alıp diğerine vererek çözmüştür. Yazar, Vayan’ı istediği yüce erdemlilikte gösterebilmek için bu örnekte olduğu gibi kimi zaman ifrata kaçabilmektedir.

Mari: Piyes'in diğer ana karakteridir. Mösyö ve Madam Loan’ın kızlarıdır. Piyesin başında, "okumuş, ciddi, ağırbaşlı, genç ve yirmi bir yaşında" olarak tavsif edilir. Bu kahraman da Turfanda mı Yoksa Turfa mı? romanındaki Zehra karakteri ile önemli oranda örtüşen bir karakterdir. Hayata bakışı, yaşam biçimi ve hayat algısı yaşıtı olan diğer kızlardan oldukça farklıdır. Bilime, sanata, okumaya ve eleştirmeye meraklıdır. Bu yaşına kadar evlenmemiş olması başta annesini ve etrafındakileri endişelendirmektedir. Annesinin görüşlerini benimsememekte ve eleştirmektedir. Bu bakımdan en önemli yol göstericisi babasıdır. Annesinin geleneksel yaşam biçimi dayatmasına, babasını yanına alarak karşı koymaya çalışır. En önemli çatışmayı ise evlilik konusunda yaşamaktadırlar. Ancak Mari, akıllı ve saygılı bir genç kızdır. Asla annesine saygısızlık etmez. Sevecenlikle gönlünü almaya çalışır. Bu durum da, Murad Bey’in karakteri vasıtasıyla imrendirmeye çalıştığı bir diğer ahlâki olgudur.

Madam, Mari’yi birçok açıdan tenkid eder. Ona göre Mari muteber bir genç kız olmaktan çok uzak davranış kalıpları benimsemiştir. Mösyö ise kızının geldiği entelektüel seviyeden oldukça

87 Mizancı, Tencere Yuvarlandı Kapă̆ını Buldu, 6 
hoşnut ve mağrurdur. Karı koca arasındaki en önemli çatışmalardan biri de bu genç kızların tahsili meselesi üzerinedir. Madam bir genç kızın en önemli vazifesi olabildiğince bakımlı ve güzel görünerek zengin ve itibar sahibi bir koca bulabilmektir. Oysa Mari'nin, "hanımlıktan kadınlıktan eser kalmamış, erkekten berbat bir şey olmakla emsali kalmamıştır." ${ }^{88}$ Madam ve Mösyö'nün aynı zamanda sosyal bir ortam da olan tiyatrodan istifade biçimleri bakımından da ayrı dünyalara mensupturlar. Madam'a göre, "Kız kısmı tiyatroya gider. Hep kibarların âdetidir. Lakin kız kısmı tiyatroya anasıyla beraber gider. Sahnede ne olup bittiğine dikkat etmez bile. Kendi gibi genç kız ve kadınların süs ve nizamlarına ve tavır ve hareketlerine bakarak tabiat ve terbiyece olan noksanlarını ikmale çalışır." ${ }^{89}$ Oysa Mari, tiyatroya babasıyla gidip, sahnede olup biteni muhakeme eder. Muhakemesinin doğruluğunu ertesi günün gazetesinden takip eder. Dünyanın her yerinde olup bitenden haberdar olmak ister. Mari'nin bu davranışlarına eve gelen misafirlerin ettikleri iltifatlar noktasında da karı koca ihtilafa düşmektedir. Mösyö, bu iltifatlardan oldukça gurur duyarken Madam onların aslında iltifat değil istihza olduğunu savunur. Yazar bu konuyu başka bir bakıştan daha değerlendirmediği için Loanların çevresinin entelektüellik seviyesi hakkında pek fikir edinememekle birlikte Mösyö Loan'ın çevresinin kendi dünya algısına yakın olacağına kanaat getirmek daha mümkündür. Bununla birlikte Mari’ye çevredekilerin dediği, “erkekte bile bu vukuf ve bu kalem nadir bulunur." İfadesi bugün için dikkate değerdir. Zira cinsiyetin herhangi bir etken güç olmadığı bilgi seviyesi ve ifade gücü gibi bir konuda da erkeğin üstünlüğünün vurgusu vardır. Bu ifade, piyesin yazıldığı dönemin zihniyetinin kadın erkek ayrımına bakışını yansıtması açısından da önemlidir. Bununla birlikte Madam'ın sıklıkla kullandığı “kız kısmı” ifadesi o dönemde oldukça normal görünen ancak cinsiyetçi söylemin önemli bir çağrışımı olan bir ifadedir. Kızların karakterlerinin beklenti, duygu ve düşüncelerinin kendine has ve herkesten farklılık arz edebileceği düşüncesinin tamamen aksine bütün kızları kız cinsiyetlerinin yüklediği ortak ve toplumsal tek kimlikte birleştiren bir söylemdir.

Madam'ın Mari'nin odasının diğer kızları odalarından ne kadar farklı olduğunu ifade için yaptı̆̆ 1 tasvir Mari'yi yakından tanımamıza yardımcı olur. Aslında o her şeyi "kız kısmı”nın ihtiyacına uygun olarak hazırlamıştır. Lakin Mari, “çekmenin pudra ve saire gibi tualet gözlerine bir takım böcek kuruları ile taş ve maden parçaları koymuş, lavanta şişelerine fotoğraf vesair eczaları dökmüş, saç maşalarını atıp yerine pergel, cetvel, hurdebin gibi münasebetsiz şeyler doldurmuş. Masanın üstüne çiçek demeti yerine pis bir küre koymuş. Duvara resim ve halı yerine haritalar asmış... Kazaen odasına girince bitpazarının hurdacı dükkânına girdim zannediyorum." 90

Mari, yazarın tek romanındaki Zehra karakteri gibi kendisini yetiştirmiş, muhakeme yeteneği gelişmiş bir karakterdir. Sorgulamadan ya da aklına yatmayan bir şeyi ona kabul ettirmek oldukça zordur.

88 Mizancı, Tencere Yuvarlandı Kapağını Buldu, 15.

89 Mizancı, Tencere Yuvarlandı Kapağını Buldu, 15.

90 Mizancı, Tencere Yuvarlandı Kapağını Buldu, 16-17. 
Ernest Lömon: Piyesin menfi karakterlerinden biridir. Eserin başında, "Yirmi altı yaşında, sathi, meslek ve mezhepten mu'arra, şık, sefahate dalmış, rütbe ve memuriyetçe terakkiyi aksayı emel bilmiş bir genç." Olarak tanıtılır. Madam'ın kızına uygun gördüğü eş adayıdır. Madam kızına Ernest'i uygun bulmasında etkili olan özelliklerini ise şöyle sıralar: "Babasının tek oğludur. Babası memuriyeti maaş ve itibardan başka elli bin Frank irad-1 seneviyesine maliktir. Anası zadegândır. Onun da beklediği miraslar pek çoktur. Oğullarının da babası sayesinde bin Frank aylığı rütbesi, nişanı vardır." ${ }^{91}$ Madam'ın gözünde Ernest'i iyi ve güzel gösteren hasletlerin tamamı görüldüğü gibi maddiyata, makam ve mevkie mütealliktir. Mösyö Ernest, işinde yükselmek istemektedir. Bunun için de bulabildiği en kısa yol evlenmektir. Çünkü "hovarda-meşrep" müdürü kimin karısı güzelse ona meyil göstermektedir. Bu bakımdan Ernest, yükselebilmek için güzel bir hanımla evlenmek ister. Ernest Lömon ilk önce Loanların da komşusu olan bir üniversite hocasının kızına talip olmuştur. Ancak kızın babası mektepten kovulmuş öyle bir beyinsize verilecek kızım yoktur.” Diyerek reddetmiştir. Ardından Ernest'in annesi Mari'nin annesiyle konuşarak söz almıştır. Çünkü Madam Loan devrin bütün geleneksel anneleri gibi kızın eşini seçmeye hakkı olmadığını düşünmektedir. Anne babasının sözünü kâfi görmektedir.

Ernest'in, evlenme kararı vermeden Adel'le bir münasebeti vardır. Bu münasebet noter imzalı bir de sözleşmeye bağlanmıştır. Ernest'in iptal etmeye çalıştı̆̆ aralarında çıkan anlaşmazlığı da yine Vayan çözüme kavuşturur.

Ernest, tanışmak için Loan'ların evine gittiği zaman Sofi ile karşılaşır. Sofi’yi oldukça beğenir. Hatta Mari'den ret cevabı aldığında dönüş yolunda Vayan'a Sofi yerine yanlışlıkla Mari'ye talip olduğunu ima eder tarzda konuşur. Aslında Ernest ve Sofi hayattan beklentileri açısından denktirler.

Sofi Person: Madam Loan'ın kız kardeşinin kızıdır. Eşhas kısmında, Madam tarzında, Mari'nin yaşında ve havai olarak tanımlanır. Piyesin sonlarına doğru Vayan'ın Ernest'e anlatımı sayesinde Sofi tanıtılır, "Matmazel Person, anasız ve babasız olarak madamın elinde kalmış ve madam tarafından terbiye edilmiş bir kızdır. Anasından ve babasından bir hayli miras kaldığı gibi kendi kızının gidişinden hoşnut olmayan Madam Loan dahi Matmazel Person'u asıl evlat edinip nesi var nesi yok ise ona vermiştir. Nazarında Matmazel Mari'nin kocasına değil, Matmazel Sofi'ninkine damadım diyecekmiş." 92

Sofi, Murad Bey'in edebiyat-1 ahlâkiye anlayışı açısından değerlendirildiğinde ahlâken düşük bir kızdır. Bu yüzden de menfi karakterler arasındadır. Ernest'in yükselmek arzusuyla amirlerinin beğeneceği güzellikte biriyle evlenmek istemesi Mari, için oldukça ahlâk dışıken Sofi, bunu evleneceği kişi açısından lehte bir durum olarak algılar: "Müdürüne hoş görünmek için karısına her türlü müsaadede bulunacak demektir. Genç, zengin olmakla beraber kıskanmayıp karısının eğlenmesine müsaade eden kocalar binde bir bile bulunmaz." 93 Bu sözleri Sofi'nin ahlâki seviyesini göstermesi açısından önemlidir. Bununla birlikte Mösyö Loan'ın da Sofi

91 Mizancı, Tencere Yuvarlandı Kapă̆ını Buldu, 12.

92 Mizanc1, Tencere Yuvarlandı Kapağını Buldu, 91-92.

93 Mizancı, Tencere Yuvarlandı Kapağını Buldu, 22. 
hakkındaki görüşü onun ahlâkının tam da Mösyö Lömon'a uygun olduğu yönündedir: “Tabiat ve terbiye itibariyle Madam Loan'ın tıpkısı ahlâk itibariyle bir iki derece aşağısıdır... Kızın aklı başında bir adama teklif olunacak bir sıfat-1 mânevisi yoktur. Yalnız zahiren güzel ve zariftir. Ancak Lömon gibi zahir beyinlerce çekilebilinir bir afettir."94

Adel: Piyeste oldukça pasif görünen bir karakterdir. Bu karakterin en önemli yanı ahlâken düşük olduğu için menfi tarafta olması gerekirken, bu âleme kazaen düştüğü ve kurtulmak istediği için müspet karakterler içinde yer almasıdır. Eserin başında, "Aslında cevherli, kazaen fena âleme düşmüş bir biçare" olarak tanıtılır. Adel'in bu piyesteki en önemli vazifesi Vayan'ın ahlâki üstünlüğünü pekiştirmektir. Vayan, Adel'in içinde olduğu kötü yaşantıdan kurtulma ve tövbekâr olma isteğine madden ve manen destekleyerek köyüne dönüp sade bir hayat yaşaması için destek olur. Adel, Vayan’a âşıktır. Bir gün aşkını Vayan'a açmış ve ret cevabı almıştır. Adel'in bu bunalımlı ve üzgün halinden istifade eden ve yıllardır onunla evlenmek isteyen bir gence teslim olur. Ancak sonrasında bu genç onunla evlenmeyi istemez. Adel için bundan sonra kötü günler başlamıştır. Paris'e gelmiş Prens Lapkin ve Ernest Lömon'la gayrimeşru ilişki yaşamıştır. Adel bu ilişkileri sadece geçinmek için yaşamıştır. Ve sadece hayatında bu iki kişi olmuştur. Adel ve Vayan'ın konuşmalarından edindiğimiz bu bilgiler, bize hem Adel'i hem de Vayan'ı biraz daha tanıtır. Vayan, kendisine o vakitte şimdi de bütün varlığıyla teslim olmaya hazır bir kadına başka birini sevdiği için asla ümit vermemekle, hatta onu vazgeçirebilmek için kaba ve sert konuşmakla Mîzancı Murat'ın istediği ahlâk anlayışını sergilemiştir.

Evlenmek için çabalayan Ernest, Mari'den de ret cevabı aldıktan sonra kendisiyle vedalaşmaya gelen Adel'e de aynı teklifi yapar. Çünkü ona göre: “Kör şeytan aklıma ne getirdi bilir misiniz? Evlenmek istiyorsan şu Adel'in nesi eksik? İki kişiye metres olmuş bir kadın alınır mı diyerek bizim sürü şüphesiz kıyamet koparır. Lakin alenen metres olmuş olanlarla olmayanların farkını bana sorunuz. ${ }^{" 95}$ Ancak Adel, bu teklifi reddeder. Çünkü Mari'nin Ernest'i neden reddettiğini bilir. Ve bu durumun çirkefe düşmüş biri için bile kabul edilebilir olmadığını savunur. Bu tavır Adel'i de benzerleri için bir rol model yapmaktadır. Belki onun bu davranışı toplumda bu yoldaki insanlara tövbekârlık yolunu açacaktır.

\subsection{Edebiyat-ı Ahlâkiye Tezinin Piyese Yansımaları}

Mîzancı Murad, edebiyat konusundaki görüşlerini ayrıntılı ve dönemin meşhur eserlerine intibak ettikten sonra, kendisi bu yolda yazılmış eserin örneğini vermek amaçlı bir roman ve bir tiyatro eseri neşretmiştir. Romanı, bugün bile birçok edebi araştırmanın konusu olmaya devam ederken, piyesi bazı edebiyat tarihlerinde sadece ismen geçmektedir. Dahası bugüne kadar günümüz Türkçesine çevrilmiş baskısı da bulunmamaktadır. Murad Bey, piyesinde de romanında da tenkitlerinde 1srarla vurguladığı edebiyat-ı ahlâkiye anlayışına hizmet eden prototip karakterler yaratmıştır. Her ne kadar bu karakterler bir idealin kurguladığı prototipler

94 Mizancı, Tencere Yuvarlandı Kapağını Buldu, 79.

95 Mizancı, Tencere Yuvarlandı Kapağını Buldu, 84 
ise de tamamen gerçek dışı ya da fantastik kurgu kişileri değildir. Ancak, söz konusu dönemde bu tip kişilerin pek bulunmadığ 1 ya da istisna oldukları da bir gerçektir. Bununla birlikte vaka silsilesi toplumsal yapıyı bire bir yansıtacak kadar gerçekçidir. Anlatıcı tezini savunabilmek için kötü örnekleri de sergilemek durumundadır. Ancak okuyucuların bu gibi olumsuzluklarla da özdeşim kurmaları tehlikesinin önüne geçebilmek adına kahramanlarını Batılı seçmiştir. Böylece iyi örneğin rol model oma ihtimalini arttırmaktadır. Murad Bey'in en önemli iddiası toplumsal yapımızdaki aksaklık ve yanlışlıkların, Mansur Bey, Zehra Hanım, Vayan ve Mari gibi şahısların sayısını arttırarak düzeltilebileceğidir. Böylece romanında İstanbul'a ilk defa gelen Mansur'un dilinden dediği gibi “Şüphem yoktur. İstikbalimiz, mazimize bile gıpta ettirecektir." ${ }^{" 96}$ hayalini gerçekleştirmiş olacaktır.

Edebiyat-1 Ahlâkiye, Murad Bey’in Batı eserlerinde müşahede ettiği bir yaklaşımdır. Batılı yazarlar roman ve tiyatrolarında yetenekli toplumsal seçkinler yaratarak toplumsal yapıyı bu ideal rol modeller vasıtasıyla iyiye yöneltmeyi amaçlamaktadırlar. Eser hem gerçekçi olmalı toplumsal yapıyı yansıtmalı hem de millî ve ahlâki normlara riayet etmelidir. Edebi eserin en önemli misyonu iyiye özendirip kötü olandan uzaklaştırmaktır.

Tencere Yuvarlandı Kapağını Buldu, edebiyat-ı ahlâkiye anlayışı açısından yazarın diğer eserleri gibi proje bir eserdir. Yazarın edebi tenkitlerinde dile getirdiği edebi görüşlerini uyguladığı bir diğer tatbikat sahasıdır. Daha önce mevcut edebi eserlere yaptığı değerlendirmeler ile savunduğu görüşlerinin vücut bulmuş şeklidir demek yanlış olmayacaktır.

Eserin en önemli özelliği ilk bakışta çeviri ya da uyarlama bir eser zannı yaratan yabancı isimlerdir. Murad Bey, kahramanlarına yabancı isimler vermeyi, başkahramanının yüksek erdemini vurgulamak için piyese yerleştirdiği olumsuz ve gayriahlâki durum ve kişilerin de rol model olabileceği kaygısıyla tercih etmiş olmalıdır. Piyeste Ernest'in evlenmeyi düşündüğü kadını patronuna beğendirmeye çalışması ya da Adel'in bir hayat kadını oluşu bu olumsuzlukların başlıcalarıdır. Olumsuz örneğin de örnek teşkil etmesi ve genç beyinlerin özdeşim kurabilecek olma ihtimali Murad Bey'in yapmaya çalıştı̆̆ının tam tersi bir etkiye neden olmamak için aldığ bir tedbirdir. Bununla birlikte edebi eserin ahlâki normlara ve toplumsal yaşayışa uygun olması gerektiği konusundaki net tutumuna karşılık piyesteki bu gayri ahlâki durumlar eleştiri sebebi olabilirdi. Bu yüzden kahramanların ecnebi oluşu ahlâki normları başka bir topluma bağlamaktadır.

Murad Bey'in piyes boyunca birkaç aile yaşantısı üzerinden imrenilecek ve iğrenilecek durumları sergilediği görülmektedir. Piyesteki en etkin aile modeli Loanlardır. Mösyö Loan, aile fertlerine yaklaşımı, dürüst, namuslu oluşu bakımından iyi bir örnektir. Geleneklere karşı değildir ancak, insanın aklını kullanması ve kendisini yetiştirmesi gerektiği düşüncesi ile hareket eder. Ve bu konuda kızına da en önemli örnek de kendisidir. Madam Loan da aslında ahlâksız bir tip değildir. Sadece kendisini yetiştirememiş, geleneksel olana fazla takılı kalmıştır. Çağın gereklerini görmekte zorlanmaktadır. Bu anlamda anne baba Loanlar yazarın çocuk eğitimi konusundaki mesajının taşıyıcısıdırlar.

96 Mehmed Murad Mizancı, Turfanda mı Yoksa Turfa mı? haz. Tacettin Şimşek (Ankara: Akçă̆ Yayınları, 1999 a), 19. 
Piyes'in başkişisi Mari Loan en önemli müspet rol model tasarımıdır. Terbiyeli, saygılı ve iyi eğitimlidir. Hayattan ne beklediğini iyi bilir ve makam ya da varlık için değerlerinden vaz geçmez. Mari'nin erdemlerini pekiştiren kişi ise yaşıtı ancak karakterce karşıtı Sofi'dir. Ernest' in evlenmek isteme sebebi karşısında bu iki kızın verdiği tepkinin zıtlığ 1 yazarı ahlâki mesajı açısından amacına ulaştırır.

Yazar, sadece aile hayatı açısından değil iş hayatı açısından da erdemli, yüksek ahlâka sahip karakterleri, olmayanlarla kıyaslayıp yüceltir. Mösyö Loan'ın işyerinde başına gelen olay oldukça önemlidir. Mösyö Loan'in piyes'in sonunda işten el çektirilme sebebinin ve masumiyetinin ortaya çıkması karakteri biraz daha yüceltir. Çünkü Mösyö, hem işinde dürüsttür hem de yanlış yapan genç birinin istikbalini ve ailesinin itibarını düşünecek kadar yüce insani değerlere sahiptir. Mösyö Loan, bu iyiliği yüzünden işinden olmasına rağmen söz konusu gencin suçunu açığa vurmamıştır. Olayın açığa çıkması ise bu gencin babasının olayı öğrenmesi sonucu olmuştur. Bu küçük olay vasıtası ile de çalışma ve iş ahlâkı konusunda muhatabına mesajını vermektedir.

Yazarın edebiyat-1 ahlâkiye tezini en büyük oranda yüklenen piyes kişisi ise Vayan'dır. Vayan, dürüst, çalışkan, iyi ahlâklı biridir. Babasının sağlayabileceği iş imkânını reddedip kendi imkânları ile hayatını kazanmayı tercih etmiştir. İşini iyi ve dürüstlükle yaptığı için oldukça iyi kazanmaktadır. Mari’yi sever ancak onun sevgisinden emin olmadığı için ve babalarının arasındaki meseleden dolayı için evlilik talebine cüret edemez. Ernest ile o kadar zıt karakterlerdir ki Vayan'ın davranışları karşısında Ernest onun bir aziz olduğunu düşünür. Çünkü Ernest çıkarcıdır. Oysa Vayan, insanların anlaşmazlıklarını gidermek ve problemlerin hallolması için ödün verebilen biridir. Mari’ye olan aşkının çaresizliği ona intiharı bile hatırlatır. Ancak burada yazar kahramanı vasıtasıyla bunun yanlışığıına da dikkat çekerek bu durumdaki gençlere mesajını verir. Ona göre can, korunması gereken ilahi bir emanettir. Dahası intihar, zayıf ve korkakların işidir. Vayan yine de ümidi kesmemesi gerektiğini düşünür. Maceranın sonu onu haklı çıkarır.

Yazar piyes boyunca kurguyu vereceği mesaja ve önerdiği eser kriterlerine uygun olarak tasarlamıştır. Piyes, komedidir. Ancak gülünç unsur neredeyse yoktur. Örneğin, Şair Evlenmesi'nde gördüğümüz ortaoyunu tiplerine benzer tipler ya da yanlış anlamalara dayalı güldürü unsurları hiç yoktur. Eser, çoğu zaman dram türü özellikleri gösterir. Bir örnek verecek olursak Adel'in yaşadıkları hayatın gerçeğidir. Ve güldürü barındırmaz. Eserin komedi yönü sonunda her şeyin tatlıya bağlanması, herkesin dengine göre birini bulması ile seyirci/ okuyucunun eğlenmesidir.

\section{Sonuç}

Mîzancı Murad, Tanzimat döneminin en aktif aydınlarından biridir. İstanbul'a gelmek hayalini gerçekleştirdikten ve şans eseri önemli vazifeler aldıktan sonra devlet teşkilatındaki aksaklıklardan oldukça rahatsız olmuştur. Tanzimat Dönemi’nin diğer önemli aydınları gibi ülkedeki bütün bu aksaklık ve yozlaşmalara çözümler düşünmüş ve ifade etmek istemiştir. Bunun için en uygun vasita ittihaz ettiği Mîzan gazetesini bu amaçla neşretmiştir. Gazetenin 
yayın politikası Murad Bey'in hayat felsefesi ile örtüşmektedir. Murad Bey, Batı'nın çok gerisinde olduğumuzun bilincindedir. Çözüm önerileri vardır. Mîzan, yayın hayatı boyunca yanlış gördüğü her şeyi dile getirmekten çekinmeyen bir yayın organı olmuştur. Bu yüzden sık sık sansüre uğramıştır. Mîzan gazetesindeki yazılarında Murad Bey, siyasi, sosyal, ekonomik ve edebi meselelerden bahsettiği yazılar neşretmiş çözüm önerileri sunmuştur. Edebiyat hakkındaki makaleleri ise genellikle ahlâki edebiyat savunusu etrafında şekillenmiştir. Bu savını dönemin önemli edebi mahsullerini eleştirmek yoluyla kamuoyuna ifade etmeye çalışmıştır. Ona göre edebi metin topluma rol model teşkil edebilecek seçkinler yaratmalıdır. Böylece edebi metin toplumsal ve ahlâki yapıyı yıkıcı, bozucu değil onarıcı ve düzeltici bir misyon üstlenmelidir. Mîzan gazetesinde "Üdebamızın Numune-i İmtisalleri” başlığı ile seri makalelerle edebiyat hakkındaki teorik görüşlerini sıralayan Murad Bey, iki eseri vasıtasıyla da bunu pratiğe dökme denemesi yapmıştır. Bunlardan ilki Turfanda mı Yoksa Turfa mı? adını verdiği romanı diğeri ise çalışmamıza konu olan piyesidir. Her iki eserinde de kahramanlarının yaşantıları, söylemleri vasıtasıyla toplumsal meselelere, çarpıklıklara ve olması gereken modellere dikkat çeker. Her iki eserinde de edebiyatın toplum ahlâkının düzeltilmesine ve yükseltilmesine hizmet etmesi gerektiği düşüncesi ile hareket etmektedir. Bu durum her iki eserde de ideal karakterler kurgulamasını gerektirmiştir. Murad Bey, ilerde toplumunun fertlerini eserlerinde yarattığı prototiplerden müteşekkil görmeyi arzulamaktadır. Böylece bir aydın olarak kalemi ile ülkesine, İslam'a ve milletine hizmet etmiş olacaktır.

Tencere Yuvarlandı Kapă̆ını Buldu, dört perdelik bir komedi olarak kurgulanmıştır. Konu oldukça basittir. Çünkü yazarın asıl amacı tezini seyirci/okuyucuya kolaylıkla savunabilmektir. Kompleks bir kurgu ya da kahramana rastlamamaktayız. Kahramanlar yazarın dünya görüşüne uygun olarak menfi veya müspet bir görünüş sergilemektedirler. Metnin tamamında ahlâki ve toplumsal yapıya aykırı yaşam sürenlerin eleştirildiğini görmekteyiz. Eserde ideal kadın ve erkek modellerinin net şekilde çizilmiş olması önemlidir. Yazılarında eleştirdiği sırf Batı'da var diye İslami yapıya aykırı yaşam biçimini eserine yansıtmamıştır. Hatta daha bunun net şekilde önüne geçmek için kahramanları Fransız'dır, olay da Fransa' da geçmektedir. İsminden de anlaşılacağı üzere piyes, yanlış kriterlere dayalı evlendirme çabalarının doğurabileceği sonuçlar ve bunun aklıselim ile önüne geçilmesini konu almaktadır. Eserin sonunda herkesin dengini bulması ve mutlu olması, Murad Bey’in savının yaratacağı bilinçaltı mesaj açısından oldukça doğru bir kurgu olmuştur.

Murad Bey'in bugünün poetik bakışlarına yansımasının yerinde olacağ “ "edebiyat-1 ahlâkiye" tezi bu eserde önemli ölçüde vücut bulmuştur. Bu bakımdan eserin edebi ve akademik çevrelerce tanınmasının ve değerlendirilmesinin yerinde olacağı kanaatimizdir.

\section{Kaynaklar}

Emil, Birol. "Mîzancı Murad Bey'in Edebiyat Ve Tenkide Dair Görüşleri”, Türk Dili ve Edebiyatı Dergisi 19 (1971):119-143. Erişim 10 Mayıs 2019. http://journals.istanbul.edu.tr/iutded/article/viewFile/ 1023017660/1023016903 
Emil, Birol. Mîzancı Murad Bey Hayatı ve Eserleri. İstanbul: Kitabevi, 2009.

Ergişi, Ayşegül. Mîzan Gazetesi Inceleme, Tahlili Fihrist, Seçme Yazılar (Kahire Dönemi 159-184; ParisCenevre Dönemi 1-29; II. İstanbul Dönemi 1-135 Sayllar). Yüksek Lisans Tezi, Fatih Üniversitesi, 2007.

Karakuş, Gülbeyaz. Osmanlı Siyasi Düşüncesinde Yeni Üslup Arayışları Mîzan Gazetesi Örneği. Yüksek Lisans Tezi, Marmara Üniversitesi, Sosyal Bilimler Enstitüsü, İlahiyat Ana Bilim Dalı, İslam Felsefesi Bölümü, 2007.

Mîzanc1, Mehmed Murad "Mebahis-i Edebiyye”, Mîzan, 5 Kasım 1886b.

Mîzanc1, Mehmed Murad. “Evrak-1 Havadis”. Mîzan, 2 Haziran/33, 1887.

Mîzancı, Mehmed Murad. "İfade-i Mahsusa”, Turfanda mı Yoksa Turfa mı? İçinde, Hazırlayan Tacettin Şimşek. Ankara: Akçağ Yayınları, 1999b.

Mîzanc1, Mehmed Murad. "Mebahis-i Edebiyye”, Mîzan, 4 Kasım 1886a.

Mîzancı, Mehmed Murad. "Üdebamızın Numune-i İmtisalleri”, Yeni Türk Edebiyatı Antolojisi III içinde, 377- 515, Hazırlayan M. Kaplan, İ. Enginün, B. Emil, Z. Kerman. İstanbul: İstanbul Üniversitesi Edebiyat Fakültesi Yayınları, 1979.

Mîzanc1, Mehmed Murad. Hürriyet Vadisinde Bir Pençe-i Istibdat, Hazırlayan Ahmed Nezih Galitekin. İstanbul: Nehir Yayınları, 1997.

Mîzanc1, Mehmed Murad. Meskenet Mazeret Teşkil Eder mi?, Hazırlayan Aladdin Fidancı. İstanbul: Şehir Yayınları, 2005.

Mîzancı, Mehmed Murad. Tencere Yuvarlandı Kapağını Buldu. İstanbul: Dersaadet, 1908.

Mîzancı, Mehmed Murad. Turfanda mı Yoksa Turfa mı?, Hazırlayan Tacettin Şimşek. Ankara: Akçağ Yayınları, 1999a.

Mîzanc1, Mehmed Murad. Turfanda mı Yoksa Turfa mı?. İstanbul: Sis Yayıncılık, 2013.

Mîzanc1, Mehmed. Mîzancı Murad Bey’in II. Meşrutiyet Dönemi Hatıraları. Hazırlayan Celile Eren Argıt. İstanbul: Marifet Yayınları, 1977.

Moran, Berna. Türk Romanına Eleştirel Bir Bakış I. İstanbul: İletişim Yayınları, 2007.

Nas, Halef. “Mîzancı Murat ve İsmail Gaspıralı'nın Telif ve Tercüme Eserlere Dair Eleştirel Yaklaşımları”, Yeni Türk Edebiyatı Dergisi 12 (2015): 139-157.

Polat, Ferihan ve Gündüz Derer. "Türk Siyasi Tarihinde Muhafazakâr Batılılaşma Yanlısı Bir Jöntürk: Mîzancı Murad”, Uluslararası Sosyal Araştırmalar Dergisi, 9/43 (2016): 882-890.

Rasim, Ahmed. Matbuat Hatıralarından Muharrir, Şair, Edib. Hazırlayan A. İhsan Kolcu. Erzurum: Salkımsöğüt Yayınları. 2016.

Saraçoğlu, Ahmet Cemaleddin. Unutulan Meşhurlarımızdan Mîzancı Murad. İstanbul: Şema Yayınları, 2005.

Şirin, Zuhal. Mîzan Gazetesi Inceleme, Tahlili Fihrist, Seçme Yazılar (Birinci İstanbul Dönemi 1-159. Sayılar). Yüksek Lisans Tezi, Fatih Üniversitesi Sosyal Bilimler Enstitüsü, 2007.

Tanpınar, Ahmet Hamdi. On Dokuzuncu Asır Türk Edebiyatı Tarihi. İstanbul: Çağlayan Kitabevi, 1997.

Tansel, Fevziye Abdullah. "Mîzanc1 Mehmed Murad Bey”, İstanbul Üniversitesi Edebiyat Fakültesi Dergisi, 2/3-4 (1952): 67-88.

Uçman, Abdullah. “Mîzan”. İslam Ansiklopedisi. 30: 213-214. İstanbul: Diyanet Vakf1 Yayınevi, $2009 \mathrm{~b}$.

Uçman, Abdullah. "Mîzancı Murad”. İslam Ansiklopedisi. 30: 214-216. İstanbul: Diyanet Vakfı Yayınevi, $2009 a$. Ülken, Hilmi Ziya. Türkiye’de Çăgdaş Düşünce Tarihi. İstanbul: Ülken Yayınları, 2005. 